Maurice A. Deane School of Law at Hofstra University Scholarly Commons at Hofstra Law

Hofstra Law Faculty Scholarship

2007

\title{
"This is a Courtroom, Not a Classroom": So What is the Role of the Clinical Supervisor?
}

Jennifer A. Gundlach

Maurice A. Deane School of Law at Hofstra University

Follow this and additional works at: https://scholarlycommons.law.hofstra.edu/faculty_scholarship

\section{Recommended Citation}

Jennifer A. Gundlach, "This is a Courtroom, Not a Classroom": So What is the Role of the Clinical Supervisor?, 13 Clinical L. Rev. 279 (2007)

Available at: https://scholarlycommons.law.hofstra.edu/faculty_scholarship/116

This Article is brought to you for free and open access by Scholarly Commons at Hofstra Law. It has been accepted for inclusion in Hofstra Law Faculty Scholarship by an authorized administrator of Scholarly Commons at Hofstra Law. For more information, please contact lawcls@hofstra.edu. 


\title{
"THIS IS A COURTROOM, NOT A CLASSROOM": \\ SO WHAT IS THE ROLE OF THE CLINICAL SUPERVISOR?
}

\author{
JENNIFER A. GundLACH*
}

In this article, Gundlach examines the appropriate educational role of the clinical supervisor beyond the confines of the law school classroom or supervision in the clinical office and more specifically, within the context of a court appearance. She begins with a narrative, in which she recounts a situation in which a judge pronounced, "this is a courtroom, not a classroom" after one of her students turned to her for consultation during a court proceeding. Gundlach uses the narrative as an opportunity to evaluate the educational nature of the courtroom for all those present, including student attorneys. She then addresses the question of who should bear responsibility for facilitating the educational experience of the student attorney in the courtroom and evaluates the merits of allowing for supporting roles beyond the clinical supervisor. She also examines and evaluates the options available to the clinical supervisor, concluding that modeling, co-chairing and any method that prevents the student from "going it alone" are too easily employed without an adequate assessment of the risks and benefits for the student, the client, and the supervisor. Gundlach contends that clinical supervisors may underestimate what they can accomplish in the education of a student attorney before a court appearance and in facilitating a reflective evaluation in the aftermath. She offers several suggestions for exercises and supervisory discussions with the student to enrich this process. She ends by suggesting that clinical supervisors can enrich their educational value for their students by modeling their own evaluation and self-reflection about their supervision and teaching. Gundlach offers a sampling of the kinds of issues and questions a clinical supervisor might draw upon in her own self-reflection and assessment of her supervision of a court appearance.

* Associate Clinical Professor of Law, Disability Advocacy Clinic, Suffolk University Law School. I would like to thank participants at the Sixth International Clinical Conference hosted by UCLA/University of London in Lake Arrowhead, CA in October 2005, as well as those who attended the Mid-Atlantic Clinical Theory Workshop hosted by American University Washington College of Law in November 2003 and the New England Clinical Theory Workshop in October 2005. The thoughtful comments and suggestions on earlier drafts were critical in the development of this article. 


\section{INTRODUCTION}

In 2001, I began as a Practitioner-in-Residence in the Civil Practice Clinic at American University's Washington College of Law, when I had the humbling occasion to return to my law school in the role of a clinical supervisor, rather than as a clinical student. When I stepped back over the threshold into the clinic space, I realized that I was trading all the anxieties that $I$ had experienced as a clinic student for the new and no less overwhelming anxieties of the clinical supervisor. I quickly came to appreciate that as a student attorney, I must not have been the only one agonizing over how to identify, analyze, and ultimately choose among an array of options at any given moment in my clinical experience.

In the second week of the fall semester, I faced an immediate "trial by fire" in supervision when I learned that I would be supervising two students on a case that was set for trial three weeks later. ${ }^{1}$ The case had been scheduled for trial in the previous spring semester, but the judge continued the case until September because the court had failed to arrange for an interpreter for the client. The former students graduated soon after and little work was done on the case over the summer. As the two student attorneys assigned to the case scrambled to prepare for their first trial, I found myself scrambling to define for myself the role that I would play as a newly-titled clinical supervisor. Like others before me, I approached this new position with little training in clinical pedagogy. ${ }^{2}$

In the previous academic year, the former clinic students had brought a civil action on behalf of the client, whom I will refer to as Mr. Lee, because Mr. Lee's former girlfriend had taken money from

1 In the Civil Practice Clinic at American University, two students are assigned to each case on the premise that there can be significant benefits to both the students and the clinical supervisor of such a collaborative arrangement. See David F. Chavkin, Matchmaker, Matchmaker: Student Collaboration In Clinical Programs, 1 Clin. L. Rev. 199 (1994) (discussing advantages and disadvantages of pairing clinic students).

2 Especially in the early years of clinical teaching, clinical supervisors moved from practice into clinical teaching with little or no training as educators and were forced to experiment with how to "best teach clinically." See Phillip G. Shrag \& Michael MeltSner, Reflections on Clinical Legal Education 20 (1998). Of course, doctrinal law professors rarely have any exposure to learning methodologies either. Thankfully, clinical scholarship in this area has exploded in the past $\mathbf{3 0}$ years and law school clinical programs are beginning to offer pedagogical training for new clinical supervisors. I am indebted to the clinical law faculty at American University's Washington College of Law who developed an extensive summer training program for new clinical supervisors to introduce them to various aspects of clinical methodology, as well as Elliot Milstein's periodic "Rounds About Supervision" held throughout the year to discuss and reflect upon issues arising in the clinical supervisors' relationships with students. That instruction, as well as my challenging discussions with the director of the Civil Practice Clinic, David Chavkin, provided me with a far more thoughtful approach to my development as a clinical supervisor. 
him while he was being evaluated in a mental institution. ${ }^{3}$ During his stay in the hospital, Mr. Lee's girlfriend visited him several times. During those visits, Mr. Lee endorsed three checks for the girlfriend to deposit in his bank account on his behalf and signed over the title to two automobiles with the expressed intent that the girlfriend sell the cars and deposit the proceeds in his bank account. Contrary to Mr. Lee's instructions, the girlfriend took the checks and the proceeds from the sale of the cars, deposited the funds in her bank account for her own use, and never visited him again. Subsequently, Mr. Lee was deemed to be competent to stand trial and pled guilty to the murder charge. He was later sentenced to life in prison. After accepting Mr. Lee's case, the former clinic students filed a complaint against the girlfriend for conversion and fraudulent inducement.

In their preparation of the case, my students assessed the evidence that had been gathered by the prior students and determined that with respect to a portion of the converted money, they lacked sufficient evidence to corroborate their client's testimony as to the actual amount taken. We did not have documentary evidence of the amount obtained in the sale of the automobiles, nor could Mr. Lee testify to it. Although the amount represented a small percentage of the overall amount of money taken by the defendant, the students still tried to consider a way to include it within the damages claimed. Without the time to engage in any further factual investigation or formal discovery, the students considered the option of calling the defendant to testify in their case-in-chief because the students believed that she would not dispute the amount she received in the sale of the automobiles, though she would assert that our client intended to give the checks and the titles to her as gifts. The students expressed concern about a variety of disadvantages of such an approach, but concluded that without independent evidence as to the additional converted funds, they should call the defendant to the stand in an effort to make their client whole for the full amount of converted funds. Accordingly, they prepared a series of questions for the defendant but did not subpoena her to appear at trial.

On the day of the trial, the students arrived at the courthouse, made sure that their client was present, and briefly went to speak with

3 The purpose of this limited narrative is to provide a foundation for pedagogical issues that I address in the remainder of the article and is in no way intended to take away from the depth of the client's story or that of the students involved. I recognize the risk of providing only a limited narrative, as well as details about my supervision sessions with students about the case, but I have attempted to maintain the confidentiality and privacy of the client and the students as much as possible. For that reason, I have taken the liberty of changing some facts relating to our preparation of the case, while at the same time provide a realistic illustration of the complexities of supervision. 
him before the judge took the bench. When the students came into the courtroom, they had only a few moments to speak with opposing counsel before the proceedings began. Only then did it dawn on them that the defendant was not in the courtroom. With no time to discuss it with me, the students rose and after a few preliminaries, made their opening argument and then called their client to the stand. ${ }^{4}$ As anticipated, Mr. Lee's testimony was somewhat vague about the actual amount of some of the converted funds. After their client stepped off the stand, the student responsible for examining the defendant stood and hesitantly asked to call the defendant to the stand. The judge looked to opposing counsel, who stood and explained that his client was in the vicinity, but because of the past abuse, was afraid to appear in the courtroom and did not wish to be present. The judge turned back to the student and noted that the defendant had not been subpoenaed to testify and asked how he wanted to proceed. The student turned around wide-eyed to me, mumbling a request for the court's indulgence and asked me what to do. Before I could answer, the judge replied testily, "This is a courtroom, not a classroom" and again asked the student what he wanted to do. The student, clearly unnerved by the judge's reprimand, turned back to the judge but did not speak. Just as I began to open my mouth, the judge went on to ask the student whether he wanted the judge to issue a subpoena from the bench. As the student momentarily gnawed on the bone thrown by the judge, opposing counsel grudgingly asked for a brief recess so that he could go find his client and bring her into the courtroom. The students' decision to call the defendant in their case-in-chief proved to have minimal effect, but they ultimately prevailed in obtaining a verdict that included damages accounting for the majority of the money alleged to have been taken by the defendant.

After leaving the courthouse that day, I began to think about my "debriefing" session with the student and what I wanted to focus on during that reflective process. I ruminated about what had happened between the student and the judge and could not help but consider the judge's statement about the courtroom, his suggestion to my student, and the implications on my role as a clinical supervisor in a courtroom. Was the judge correct in his characterization - that the court-

4 In Maryland, where the trial occurred, law students are permitted to "engage in the practice of law" and appear in court, "provided that the supervising attorney (1) is satisfied that the student is competent to perform the duties assigned, (2) assumes responsibility for the quality of the student's work, (3) directs and assists the student to the extent necessary, in the supervising attorney's professional judgment, to ensure that the student's participation is effective on behalf of the client the student represents, and (4) accompanies the student when the student appears in court or before an administrative agency." MD. CT. R. 16. 
room is not a forum in which a student attorney should be seeking assistance or some sort of educational guidance mid-stream from a clinical supervisor? I began to wonder whether such a supervisory conversation is appropriate or even possible, much less beneficial to the student or the client. If such a conversation cannot or should not take place, then I wondered what role, if any, I could play during the proceedings. ${ }^{5}$ I considered whether the courtroom can or should be a classroom for the student attorney. If so, who is the teacher?

I also rued the circumstances in which $I$ had been given a case to supervise without having played a role in its preparation or having had any exposure to the substantive area of the law. ${ }^{6}$ I noted my discomfort with the lack of control that I had over all that had been done (or not done) on the case. At first, I focused on how I would have managed the case differently as a practitioner, noting "errors" made by the students as well as my own miscalculations about the case. The more difficult task was identifying and analyzing several "missed" supervision opportunities with the students. I recognized that I had had limited time to pause and consider how best to supervise the students in what little preparation they could do before the trial. I wondered what I would have done differently had I the time to supervise and prepare the students (or the prior students) for this case. In doing so, I considered the level and type of involvement $I$ had chosen and then thought about what educational role I wanted to play in the time leading up to the courtroom and what would be most effective for the students, while at the same time providing the best representation for the client. This reflective process, simplistic and raw at the time, represented my first practical entry into clinical pedagogy.

Clinical scholarship on the pedagogical approaches to supervision has exploded in the last ten years, especially on questions about whether and when to intervene and the various methods for teaching students reflective practice. However, little has been written to tease out the appropriate educational role of the clinical supervisor beyond the confines of the law school classroom or supervision in the clinical office. This article will attempt to critically examine this issue to further inform my own approach, as well as existing scholarship on the

5 Brook Baker has contended that the dominant theory of clinical supervision is "highly educator-centric except, paradoxically, during performance itself", thus leaving a "vacuum at the center of lawyering, the moment of actual performance itself." See Brook K. Baker, Learning to Fish, Fishing to Learn: Guided Participation in the Interpersonal Ecology of Practice, 6 CLIN. L. REv. 1, 23 (1999).

6 While it is common in clinical settings for a newly-hired clinical supervisor or an individual new to clinical teaching to take over the supervision of on-going cases, this narrative illustrates the compounded difficulties of familiarizing oneself with the underlying case, while at the same time learning one's way as a clinical supervisor. 
educational identity of the clinical supervisor within the context of a court appearance. ${ }^{7}$ I conclude that I (and I suspect others) overestimated the educational role that I could play with students while in the courtroom and underestimated what I could hope to achieve with the students prior to and after the appearance.

In Part I, I begin by questioning whether the judge's pronouncement, "this is a courtroom, not a classroom," was valid. While I recognize that it may not be a primary mission in any courtroom, I contend that there is a strong educational component for advocates, both as students and as teachers. The wide acceptance of clinical programs and the implementation of student practice rules provide strong support for the theory that the courtroom is and must be an extension of the classroom for student attorneys. I also consider the dual role of the judge as educator and student. I conclude that the courtroom is a multifaceted educational site for all of the players, not just the student attorneys.

In Part II, I focus on the facilitation of the educational experience of the student attorney in the courtroom. I consider who, if any, in the courthouse is responsible for the education of the student attorney. I further evaluate the value of consciously allowing for the supporting roles of others in the courthouse. I then discuss the role of the clinical supervisor in a student attorney's court appearance. I assert that the clinical supervisor's teaching options are limited in the courtroom. I then review the benefits and drawbacks of modeling and allowing the student to "go it alone," concluding that the latter is the preferable approach.

In Part III, I contend that clinical supervisors all too easily underestimate what they can accomplish in the education of a student attorney before a court appearance and in facilitating a reflective evaluation in the aftermath. I offer several suggestions for exercises and supervisory discussions with the student to enrich this process.

In Part IV, I assert that to further enrich their educational value for the student, clinical supervisors must challenge themselves to model their own evaluation and self-reflection about their supervision and teaching. I conclude with a sampling of the kinds of issues and

7 This article is limited to a discussion of what to make of the "live-client" clinical student's courtroom experience. Certainly there is much to be learned from observations of the courtroom even when not in the position of an advocate, especially within the context of judicial externships. See, e.g., Rebecca Cochran, Judicial Externships: The Clinic Inside the Courthouse (2d ed. 1999); Gerald J. Clark, Supervising Judicial Interns: A Primer 36 Suffolk U. L. Rev. 681 (2003); Stacy Caplow, From the Courtroom to the Classroom: Creating an Academic Component to Enhance the Skills and Values Learned in a Student Judicial Clerkship Clinic, 75 Neb. L. Rev. 872 (1996); Linda F. Smith, The Judicial Clinic: Theory and Method in a Life Laboratory of Law, 1993 UTAH L. REv. 429. 
questions a clinical supervisor might draw upon in her own self-reflection and assessment of her supervision of a court appearance.

\section{The Courtroom As Classroom}

It is understandable that, from his perspective on the bench, a judge would view his workplace as a courtroom and not as a classroom. An overarching objective in any classroom setting is to educate the student(s), whereas the primary function of the courtroom is to adjudicate disputes and achieve justice for the parties. And yet, had the judge in the case above given his statement more thought, he might have acknowledged that the means by which the adjudication occurs arguably includes an educational component, even for himself.

The individuals in the courtroom have different parts to play and lawyers in particular necessarily wear different hats. ${ }^{8}$ Lawyers serve as officers of the court and thus have specific obligations to the tribunal. But they must also be zealous advocates for their clients and in so doing, have several ethical responsibilities to which they must adhere. In an effort to facilitate informed decision-making, lawyers also act as educators of the jury, the judge, opposing counsel and parties, and even for their own clients. ${ }^{9}$ Thus, a student attorney, like any other lawyer in the court, must juggle multiple roles as advocate, officer of the court, and teacher. ${ }^{10}$ Clinical supervisors might also accept any or all of these roles in the courtroom, as well as the additional one of teacher for the student attorney.

There are times in the courtroom when even the advocate, experienced practitioner or student attorney, must also be the pupil. Be-

8 The Preamble to the Model Rules of Professional Conduct acknowledges the multiple and sometimes conflicting roles of an attorney:

A lawyer, as a member of the legal profession, is a representative of clients, an officer of the legal system and a public citizen having special responsibility for the quality of justice. ... In the nature of law practice, however, conflicting responsibilities are encountered. Virtually all difficult ethical problems arise from conflict between a lawyer's responsibilities to clients, to the legal system and to the lawyer's own interest in remaining an ethical person while earning a satisfactory living.

See American Bar Association, Model Rules of Prof'l Conduct Preface (2004 ed.).

9 David Dominquez has noted that "[o]ur society often overlooks one of the most powerful roles of a lawyer: that of teaching and empowering." David Dominquez, Getting Beyond Yes to Collaborative Justice: The Role of Negotiation in Community Lawyering, 12 Geo. J. on Poverty L. \& Pol'y 55, 55 (2005).

10 Student attorneys can act as powerful educators of other practitioners, an example of which comes from the same courtroom experience described at the beginning of this article. Before the trial began, opposing counsel made a flip remark to the student attorneys about how he likes to have "fun" with cases where the other side is represented by student attorneys. During the course of the trial, the students' strong attention to their well-developed theory of the case was clear in their performance, exemplified most notably by their effective objections. Opposing counsel, on the other hand, appeared to have no case theory and, in my opinion, probably lost the case as a result. 
cause the primary function in the courtroom is the adjudication of disputes, one might argue that any instructional activity of an attorney would be overly burdensome or distracting. ${ }^{11}$ But a student, like any lawyer in practice, must abide by her ethical responsibilities, which inherently require that a lawyer remain educable and open to learning about the case and practice itself during the course of representation and throughout a court appearance. For example, the Comments to Rule 1.1 of the American Bar Association's Model Rules of Professional Conduct note that to attain competency in their representation of clients, attorneys must engage in the requisite study and/or seek assistance of another lawyer with expertise when necessary to handle a problem with which the lawyer is unfamiliar. ${ }^{12}$ Lawyers must also maintain that competency throughout the representation. ${ }^{13}$ Inherent in that maintenance requirement is that as the case proceeds, the lawyer will continually review and reexamine applicable substantive and procedural law, reflecting on their actions, and assessing the consequences of each choice and considering alternatives. While lawyers in the courtroom wear different hats as advocates and as officers of the court, professional responsibility dictates that they attain and maintain competency through on-going continuing legal education. For the student attorney, that educational responsibility is even higher.

There is broad support for the theory that the courtroom is a critical location for law students to begin learning their way as professionals. Several factors have led to increased opportunities for legal education to move beyond the boundaries of the traditional law school walls as the primary site for instruction. The social reform movements of the 1960 s led to an awareness of the need for expanded rights to legal representation. William Pincus and others began advocating their vision for fundamentally altering the scope of legal education by creating opportunities for law students to fill the gap in legal representation for criminal defendants and the poor in general. ${ }^{14}$

At the same time, clinical educators have long recognized the value of experiential learning for law students acting in a live-client representational capacity. Fifty years ago, Jerome Frank referred to courtrooms as "litigation laboratories" that offer hands-on clinical op-

11 See Fannie J. Klein, The Courtroom As Classroom: The View From the Bench, in Clinical Education for the Law Student: Legal Education in a Service Setting 96 (Working Papers Prepared for CLEPR National Conference, Buck Hill Falls, PA, 1973) (noting comments of the Honorable Robert A. Wenke).

12 See American Bar Association, Model Rules of Prof'L Conduct R. 1.1, cmts. 1 , $6(2004)$.

$13 \mathrm{Id}$.

14 SChrag \& Meltsiner, supra note 2, at 3-6. 
portunities for law students. ${ }^{15}$ Judge Shirley R. Levittan signaled her approval of the courtroom serving as a critical site for learning the art of lawyering by recognizing that "if the law is a teacher in our society, the courtroom may be utilized as a classroom for its own students." 16 The courtroom is one of many spaces in which students have numerous opportunities to engage in heuristic techniques to develop their legal practice skills, to expand their understandings of social justice, and to experience first-hand the application of legal theory to practice. Today, law schools across the country have created and continue to create a wide variety of clinical programs that offer opportunities for law students to appear in court under the supervision of a practicing attorney.

Clinical scholars find strong support in the professional learning principles set forth by social scientist Donald Schon as evidence that the most effective method for teaching law students to "think like lawyers" is to create situations where students can learn by doing in a "reflective practicum" in the field, not in the classroom. ${ }^{17}$ Unless students are exposed to "deviant traditions of education for practice traditions that stand outside or alongside the normative curricula," Schon contends that students will never effectively learn professional thinking. ${ }^{18}$ Before graduating, the law student should have the opportunity to see the world through the eyes of a practicing attorney, facing the full range of ambiguities and complexities that arise in that role and being the one to identify choices and then choose among them. ${ }^{19}$ Only when in the role will the student truly be able to learn and practice professional judgment. When representing a client, that role will often require appearing in a courtroom or other tribunal.

The growth of clinical programs and the acceptance of students appearing in court could not have occurred without the adoption of

15 See Jerome Frank, A Plea for Lawyer-Schools, 56 Y ALE L. REv. 1303, 1311 (1947). The irony is that this term connotes an environment in which some or all factors are controlled. Contrast that with the experience of being in a courtroom, where little or nothing is controlled and no amount of forethought can prepare an attorney for every possible contingency that could or will occur.

16 See Honorable Shirley R. Levittan, The Clinical Program for Law Students - A View from the Bench, in Clinical Education for the Law Student: Legal Education in A Service Setting 290 (Working Papers Prepared for CLEPR National Conference, Buck Hill Falls, PA, 1973).

17 See generally Donald A. Schon, The Reflective Practitioner: How Professionals Think in Action (1983); Donald Schon, Educating the Reflective Practitioner: Toward a New Design for Teaching and Learning in the Professions (1987).

18 See Richard K. Neumann, Jr., Donald Schon, The Reflective Practitioner, and the Comparative Failures of Legal Education, 6 Clin. L. REv. 401 , 414 (2000), citing Donald A. Schon, Educating the Reflective Practitioner 15 (1987).

19 Schrag \& Meltsner, supra note 2, at 20-22. 
student practice rules in jurisdictions across the country. The Report of the American Bar Association's (ABA) Section on Judicial Administration, which proposed adoption of the ABA's Model Student Practice Rule in 1969, stated that "the adoption of this rule will encourage law schools to provide a greater opportunity for instruction and learning in the field of trial advocacy." 20 At a minimum, student practice rules have created an obligation on the part of the bench and the bar to recognize the location of the courtroom and the representation of clients within it as a legitimate educational experience for law students. Those student practice rules which require the presence of the supervisor in court appearances seem to support the idea that clinical supervisors might extend their supervision and teaching into the courtroom, without defining how that might occur or what it might entail. ${ }^{21}$

The ABA's Section on Legal Education and Admission to the Bar has expressly extended the reach of law school education beyond the traditional classroom into courtrooms and other forums. In 2003, the ABA amended its interpretation of the rules for accreditation of law schools by expanding the definition of a "class" setting in a law school to include off-site locations. ${ }^{22}$ The ABA also adopted Interpretation 304-9 which, for purposes of law school accreditation standards, permits clinical courses to include clinical work done under the direct supervision of a clinical instructor or faculty member, regardless of where it occurs, as minutes allocated towards the minimum minutes of "regularly scheduled class sessions" needed for graduation. ${ }^{23}$ Law schools continue to create and expand clinical programs and innovative curricula to allow more opportunities for law students to get out of the traditional lecture hall and into practice settings.

Even more so than practicing lawyers, student attorneys have the

20 See American Bar Association Model Student Practice Rule, 94 Rep. of the ABA 290 (1969), cited in David F. Chavkin, Am I My Client's Lawyer?: Role Definition and the Clinical Supervisor, 51 SMU L. Rev. 1507, 1515 n. 28 (1998). Chavkin argues that the Model Rule implicitly reflects a very limited view of the clinical-supervisor-clinical client relationship, allowing for student autonomy to be maximized.

21 Many states' student practice rules, as well as the ABA's Model Student Practice Rule, do not require the clinical supervisor to be present in the courtroom in all types of proceedings. One might read the absence of such a rule as support for the notion that the educational mission of the student attorney is secondary to the student's role as an advocate. See Chavkin, supra note 20, at 1517 n. 35, App. A (1998). Another possible explanation is the recognition that the more appropriate educational role of the clinical supervisor in before and after a court appearance, but not during.

22 Peter A. Joy, Political Interference with Clinical Legal Education: Denying Access to Justice, 74 Tulane L. Rev. 235, 262 (1999).

23 Sec. of Legal Educ. and Admissions to the Bar, Am. Bar Ass'n, Standards and Rules of Procedure for Approval of Law Schools, Standard 304(b), Interpretation 304-3(e) (2004). 
opportunity in a courtroom to really be creative in applying and experimenting with lawyering skills in practice, to see first-hand the consequences of their choices and their performance, to observe and evaluate the performance of other practitioners and judges, and to learn numerous administrative and clerical tasks that are necessary corollaries to the practice of law. In short, the courtroom is a valuable extension of the law school classroom and a critical site in which student attorneys learn by doing.

\section{Facilitation of Learning in the Courtroom}

Because clinical supervisors are responsible for students enrolled in a clinical program under their supervision, they are obligated to evaluate how best to facilitate the educational experience for their students not only in the classroom, but in the courtroom and other practice settings in which their students appear. While clinical supervisors can continue to play primary roles as a teacher in the classroom or supervisor in the clinic office, they must challenge themselves to think beyond those traditional roles when students move outside of those school settings and consider how, as supervisors, they might best facilitate continued learning when students are no longer in the controlled surroundings of the law school. ${ }^{24}$

\section{A. The Role of Judges and Other Courtroom Participants in the Education of Student Attorneys}

Although the student practice rules make no explicit mention of the role that the judge ought to play as educator or supervisor of the student attorney, clinical supervisors should not conclude that this legislative silence requires them to ignore the role that the judge or other participants in the courtroom can play in the learning process. William Pincus noted that in the creation of clinical programs, legal educators have drafted into the process, whether consciously or not, judges, practitioners, and court personnel. ${ }^{25}$ The MacCrate Report warned legal educators and practitioners to "stop viewing themselves as separated by a 'gap' and recognize that they are engaged in a common enterprise - the education and professional development of the

24 Externship supervisors have spent significant time and energy developing appropriate pedagogical models for supervision and classroom instruction in response to the reality of their secondary educational role for students who are supervised by a practicing lawyer or judge outside the confines of the law school environment. See, e.g., Mary Jo Eyster, Designing and Teaching the Large Extern Clinic, 5 Clin. L. Rev. 347 (2004). Clinical supervisors for in-house clinics can draw from these sources in an effort to further develop their own educational role in relation to their students.

25 William Pincus, Opening Remarks, in Clinical Education for the Law Student 7-8 (CLEPR Conference Proceedings, Buck Hill Falls, PA, 1973). 
members of a great profession." 26 More recently, the Best Practices Project of the Clinical Legal Education Association has explicitly recommended that law schools enhance the quality of their programs of instruction "by making appropriate use of practicing lawyers and judges."27 "Appropriate use" need not be limited to classroom teaching or judicial externships. Clinical supervisors must acknowledge that the judge and other practitioners in the courtroom will play an educational role during their students' court appearances.

While the clinical supervisor might be the primary teacher in the classroom, courtrooms are not under the supervisor's sole control. Courthouses and other forums offer student attorneys multiple opportunities to observe, evaluate, and even emulate other professionals. ${ }^{28}$ Adversarial counsel or other lawyers observed in the courtroom can serve as powerful examples for students to evaluate professional standards. ${ }^{29}$ In fact, there is value for the students to observe all the individuals who appear in the courtroom: peers, other attorneys, judges, clients, court personnel, or other courtroom participants. ${ }^{30}$ Watching the varieties of practice offers student attorneys the opportunity to evaluate approaches and consider the advantages or shortcomings of any given model. Practitioners and court personnel can also provide valuable information to student attorneys about local practice or custom. ${ }^{31}$ In addition, interactions with other individuals in the court allow students to reflect on a myriad of ethical and professionalism issues. ${ }^{32}$

Student attorneys might ignore what they can learn from clients. A fundamental principle of collaborative lawyering is that lawyers and clients can educate one another by sharing skills and knowledge that have arisen from their experiences. ${ }^{33}$ For example, clients might have

26 Pincus, supra note 25, at 7-8.

27 See Best Practices Project for Legal Education 6 (Draft, updated Mar. 31,

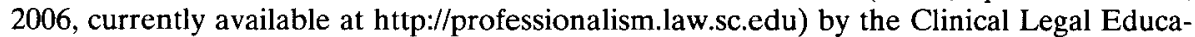
tion Association (CLEA) in conjunction with other organizations and individuals.

28 Baker, supra note 5, at 14-15, 23-24 (discussing opportunities to learn from peers, coworkers, support staff and clients).

29 See Melissa L. Breger, Gina M. Calabrese, \& Theresa A. Hughes, Teaching Professionalism in Context: Insights From Students, 55 S.C. L. REv. 303, 332 (2003) (noting that reputable attorneys can challenge the student to perform better while observation of negative role models can help students define their own sense of professionalism).

30 Schon, Educating the Reflective Practitioner, supra note 17, at 13 (recommending that students carefully study the performance of practitioners).

31 Andrea Seielstad, Unwritten Laws and Customs, Local Legal Cultures, and Clinical Legal Education, 6 CLIN. L. REv. 127, 172 (1999).

32 Breger, et al., supra note 29, at 309.

33 See, e.g., Ascanio Piomelli, Foucault's Approach to Power: Its Allure and Limits for Collaborative Lawyering, 2004 UTAH L. Rev. 395, 446-47; Gerald P. Lopez, Rebellious Lawyering: One Chicano's Vision of Progressive Law Practice 50-51 (1992). 
useful information about the systems in which they have learned to operate, how individuals within those systems think and react, how the system can be negotiated, and what other resources or individuals might be of help. Even during court proceedings, clients often provide valuable administrative and substantive lessons, insights and feedback to the attorney. The clinical supervisor can play an important role in reminding the student attorney to consider what they can learn from their client during the proceedings. ${ }^{34}$

Because of the judge's position in the courtroom and student attorneys' relationship to them, students are usually inclined to view judges as collaborative educators in their clinical experience. Many judges may consider themselves as mentors or teachers for the attorneys (including student attorneys) who enter their courtroom, or as collaborative educators with the clinical supervisors. ${ }^{35}$ Not only are they there to educate the attorneys who appear before them about the law, but they are there to educate them about procedure, appropriate conduct, and the unwritten customs of the locale, as well as that particular courtroom. ${ }^{36}$ For example, a judge may provide advice or feedback to counsel in an effort to make the attorney a stronger advocate for their client. ${ }^{37}$ In the clinic case discussed at the beginning of the article, the judge stepped into the role of educator by suggesting to the student that he could request that the judge issue a subpoena from the bench. Most clinical supervisors have encountered similar situations in which judges have offered their advice or feedback to a clinic student about the student's performance or even about strategy or procedure. ${ }^{38}$

34 In connection with these discussions, the clinical supervisor might also ask students to consider why attorneys might overlook the knowledge their clients hold and the systemic impact of devaluing this knowledge within the legal system.

35 See, e.g., Klein, supra note 11, at 93-94 (noting comments of the Honorable Alvin B. Rubin).

36 Interestingly enough, in responses to a questionnaire sent to them, 49 judges before whom clinic students had appeared stated that they did not treat students any differently from members of the bar. See Honorable Alvin B. Rubin, A View from the Bench, in Clinical Education for the Law Student: Legal Education in a Service Setting 254 (Working Papers Prepared for CLEPR National Conference, Buck Hill Falls, 1973).

37 See Bonnie McGrath, Inadvertent Mentors: The Courtroom as Classroom, Chic. Bar. Assn. Record 28-29 (April 1996) (discussing the mentoring role that judges can play for attorneys who appear before them).

38 At some point, this feedback can cross a line and the judge's responsibility to objectively try cases and administer justice may be compromised if she begins to take a more active role in educating advocates who appear before her. One California trial judge who recognized the danger of intruding on trial tactics and strategy has affirmatively stated that it is not the judge's duty to serve as a teacher in the courtroom. See Klein, supra note 11, at 96 (noting comments by the Honorable Robert A. Wenke). However, Judge Wenke did believe that he could play a role in educating lawyers about the style of presentation and courtesy to the court and counsel. Id. 
While at times the feedback or advice from a judge or even another lawyer can be valuable for the student, there is a risk that "too many cooks in the kitchen" can lead to confusion for the student. The clinical supervisor can safely assume that few judges or lawyers are well-versed in the pedagogical approaches of clinical education. ${ }^{39}$ Judges also have different means and objectives for adjudicating cases than those of the clinical supervisor. For example, busy trial judges might be more inclined to focus on efficiency and settlement and thus become impatient with students who are more accustomed to critically examining every aspect of their cases with their clinic professors. ${ }^{40}$ Alternatively, the growth of therapeutic jurisprudence in the creation of problem-solving courts may have the unintended consequence of an overly-intrusive judge who has a different set of goals in mind than what the student attorney and the client believe is best. ${ }^{41}$

Students inevitably receive mixed messages; thus, it is important for the clinician to challenge the student to think critically about what they learn from other participants in the courtroom. Student attorneys may feel inclined to view the judge or other practitioners as educational role models, but the clinical supervisor must ensure that the students do not uncritically adopt the conduct of other practitioners in an effort to feel more comfortable in their representative role. ${ }^{42}$

39 Ann Shalleck has noted that judges and lawyers are aware only of the performance of the students, not of the process that surrounds that performance. See Ann Shalleck, Clinical Contexts: Theory and Practice in Law and Supervision, 21 N.Y.U. REv. L. \& Soc. Change 109, 110-11 (1993-94). However, at least one judge has exhibited insight into the clinical method when he noted that "[o]bservance as a passive spectator can never have the impact that comes from the immersion in a constantly moving event involving a unique myriad of interacting forces. An observer can see the 'big picture' but successful advocacy is more than this." See Judge Robert A. Wenke, A View from the Bench, in CLinical Education for the Law Student: Legal Education in a Service Setring 293 (Working Papers Prepared for CLEPR, National Conference in Buck Hill Falls, PA, 1973).

40 Many clinical supervisors can likely recall situations in which a judge has grumbled about the time that a student takes to examine a witness, present an argument, or the length of a brief submitted in support of a case. Although we might commend the student for the care and time they have spent, a judge might critique the student for the mere reason that it is not the usual "culture" of the forum. See Breger, et al, supra note 29, at 344.

41 See Timothy Casey, When Good Intentions Are Not Enough: Problem-Solving Courts and the Impending Crisis of Legitimacy, 57 SMU L. Rev. 1459 (2004); Phillip D. Gould \& Patricia H. Murrell, Therapeutic Jurisprudence and Cognitive Complexity: An Overview, 29 Fordham URB. L.J. 2117 (2002). Supporters of therapeutic jurisprudence contend that there are clients, particularly those in juvenile courts, drug courts, or domestic violence courts, that would benefit from a judge who takes a more educational, active role in the proceedings. See, e.g., Jennifer Thompson, Who's Afraid of Judicial Activism? Reconceptualizing a Traditional Paradigm in the Context of Specialized Domestic Violence Court Programs, 56 ME. L. Rev. 407 (2004). Although there may be real benefits to this judicial role, clinical supervisors will inevitably face unique supervision challenges in such cases.

42 See, e.g., Robert Rader, Confessions of Guilt: A Clinic Student's Reflections on Representing Indigent Criminal Defendants, 1 CuIN. L. REv. 299, 317-18 (1994) (noting that he 
There is a danger that students will receive faulty or questionable instruction about some aspect of procedure or substantive law from judges or other practitioners. ${ }^{43}$ Likewise, the clinical supervisor's views of ethical responsibilities and professionalism may differ from the views of the judge or other attorneys observed by the students. ${ }^{44}$ Although some judges have had significant experience as trial lawyers, not all judges are experienced advocates and may not have the best advice on strategy. ${ }^{45}$ In fact, clinical supervisors have all witnessed judges who disregard or misapply evidentiary or procedural rules. ${ }^{46}$ Moreover, unlike lawyers, judges do not have a "client" in the traditional sense. ${ }^{47}$

Because the judge is in a position of authority, students might be overly timid and more inclined to give too much weight to the conduct they observe or feedback they receive from a judge, even if it is contrary to what they have determined through their own research or through discussions with their clinical supervisor. ${ }^{48}$ Similarly, student attorneys often feel very comfortable following the lead of more-experienced practitioners who give them advice, even if they are opposing counsel. Judge Harold $\mathrm{H}$. Greene has warned that if critiqued by an overly-intrusive or protective judge, a student attorney's professional self-esteem and ability to conduct himself at trial might be harmed. ${ }^{49}$ If the student places too much value on that feedback or advice, be it positive or negative, she may be unable or unwilling to take the next step to critically examine that advice from several

"felt pressure" to quickly acclimate himself to the world of the criminal courts and thus looked to more experienced criminal attorneys in court to see what they were doing).

43 See Rodney J. Uphoff, James J. Clark, \& Edward C. Monahan, Preparing the New Law Graduate to Practice Law: A View from the Trenches, 65 U. CIN. L. REv. 381, 393 (1997) (noting that lawyers who attempt to learn evidence on the job often blindly follow the evidentiary lessons of a trial judge who has a misguided notion of the evidence code).

44 Breger, et al., supra note 29, at 306.

45 See Wenke, supra note 39, at 296.

46 Abbe Smith notes some of the outrageous conduct of judges observed by her students in the lower criminal courts, including using "their contempt power like a gym teacher uses a whistle", creating new rules or disregarding others, and creating novel sanctions to control "insolent" lawyers. See Abbe Smith, Carrying on in Criminal Court: When Criminal Defense is Not So Sexy and Other Grievances, 1 CLIN. L. Rev. 723, 744 (1995).

47 David B. Wilkins, Legal Realism for Lawyers, 104 HARv. L. REv. 468, 476 (1990).

48 See Judge Harold H. Greene, Judging the Students: Judicial Attitudes on Student Practice, in Clinical Education for the Law Student: Legal Education in a SerVICE SETring 272 (Working Papers Prepared for CLEPR National Conference, Buck Hill Falls, PA, 1973) (responding to judicial concerns that students will be more contentious and will waste the court's time with frivolous arguments).

49 Id. at 271 . In response to concerns that the judge would need to play a more active role in counseling the student on strategy, Judge Greene argued that a judge is relieved of what would otherwise be a greater obligation if the student attorney were not present and the client was pro se. Id. at 271-272. 
angles.

As will be discussed more infra, the clinical supervisor can play an integral role in the student attorney's continuing evaluation of the messages received by the other participants in the courtroom, thereby enriching the overall educational experience. The principle discrepancy between the courtroom and the classroom is that classrooms encourage interaction and exchange of information to effectuate learning and understanding. ${ }^{50}$ The constraints of a courtroom, including the competing objectives at play, place severe limits on this exchange of information during the student's court appearance. Accordingly, as will be discussed in the next section, the clinical supervisor must bridge the learning between the classroom, the courtroom, and the supervisor's office.

\section{B. The Role of the Clinical Supervisor in the Courtroom}

Clinical pedagogy is firmly rooted in the belief that close beforeand after-the-fact supervision is essential. ${ }^{51}$ "Supervision" as used by a clinical supervisor is distinct from the kind of supervision which occurs between a more senior attorney and a junior attorney. ${ }^{52}$ It involves a delicate balance between giving the student the freedom to try on and experiment with the primary role of a lawyer serving a client, while at the same time making sure that the client is receiving excellent, ethical legal representation. Clinicians agree that supervision of a student attorney prior to a court appearance should involve considerable development of goals and strategy, critical analysis and consideration of all the possible issues, actions, or events that might arise, and the opportunity to practice or "moot" the performance though explicit examples of effective exercises are rare in the literature. ${ }^{53}$ Similarly, clinical supervisors have generally agreed on the importance of reflecting on the experience afterwards and there is considerable scholarship on the various ways to engage students in this process. ${ }^{54}$ Little has been written, however, about the educational role of the clinical supervisor during a court appearance.

50 B. Michael Dann, Learning Lessons and Speaking Rights: Creating Educated and Democratic Juries, 68 IND. L. J. 1229, 1244 (1993).

51 Baker, supra note 5, at 2-3. See generally Shalleck, supra note 39; Peter T. Hoffman, The Stages of the Clinical Supervisory Relationship, 4 ANTIOCH L. J. 301 (1986).

52 See. SChrag \& MeltSNer, supra note 2, at 41 (discussing initial attempt to structure clinical supervisor/student relationship as that of senior partner/junior associate, and then ultimate rejection of this model).

53 See, e.g., Seielstad, supra note 31, at 190-205; William P. Quigley, Introduction to Clinical Teaching for the New Clinical Law Professor: A View from the First Floor, 28 AKRON L. REV. 463, 477-481 (1995).

54 See, e.g., Quigley, supra note 53 , at $481-484$. 


\section{Opportunities for a Reflective Dialogue Are Limited}

The courtroom experience is one snap-shot of the overall relationship between the student attorney and the clinical supervisor and the choices available to the clinical supervisor about the role she will play in supervising the student in that representative moment. Because the courtroom can often be an important site for learning, it seems somewhat understandable that a clinical supervisor would feel inclined to view it as an extension of her classroom and thus, expect to play a primary educational role there. Because supervision is at the core of effective clinical teaching, it seems anathema not to carry that supervision into the courtroom. And yet, as noted earlier, the courtroom is a very different setting than a traditional classroom.

In the classroom and in supervision, clinicians are free to engage students in an interactive dialogue in an effort to train them to be "reflective practitioners." 55 Donald Schon, who coined the term, believed that one of the primary threats to professional competence is when the practitioner has "overlearned" what he knows and fails to reflect on his actions:

As a practitioner experiences many variations of a small number of types of cases, he is able to "practice" his practice. He develops a repertoire of expectations, images, and techniques. He learns what to look for and how to respond to what he finds. As long as his practice is stable, in the sense that it brings him the same types of cases, he becomes less and less subject to surprise. His knowing-inpractice tends to become increasingly tacit, spontaneous, and automatic, thereby conferring upon him and his clients the benefits of specialization. On the other hand, professional specialization can have negative effects. In the individual, a high degree of specialization can lead to a parochial narrowness of vision. . . Further, as a practice becomes more repetitive and routine, and as knowing-inpractice becomes increasingly tacit and spontaneous, the practitioner may miss important opportunities to think about what he is doing. 56

Schon recognized that competent professionals avoid this problem by "reflecting-in-action," whereby a practitioner can examine and critique assumptions and understandings drawn from the repetitive experiences of a specialized practice. ${ }^{57} \mathrm{He}$ might reflect on any of the

55 In his two ground-breaking texts, Donald Schon asserted that the answer to the "crisis of confidence in professional knowledge" that he saw in the 1970s and 80s was for professional schools to train students to become "reflective practitioners." See generally Schon, The Reflective Practitioner, supra note 17; Schon, Educating the ReflecTIVE Practitioner, supra note 17.

56 Schon, The Reflective Practitioner, supra note 17 , at 60-61.

57 Id. at 61-62. 
following: the tacit norms and appreciations which underlie his judgment, the strategies and theories implicit in a pattern of behavior, the feeling for a situation which has led him to adopt a particular course of action, the way in which he has framed the problem he is trying to solve, or the role he has constructed for himself within a larger institutional context. ${ }^{58}$ Schon contended that reflective practitioners are better equipped to face the "uncertainty, uniqueness, and conflict" in the "indeterminate zones" of professional work by reflecting in action and having a reflective conversation with the situation. ${ }^{59}$

The courtroom is one of those indeterminate zones. In the case of the legal practitioner, effective lawyering involves problem-solving, decision-making, and the use of practical judgment. ${ }^{60}$ Thus, the clinical supervisor's objective is to create a learning situation in which "students become proficient in a kind of reflection-in-action" by engaging in "a dialogue of coach and student that takes the form of reciprocal reflection-in-action" in the performance of these skills. ${ }^{61}$

In an ideal educational situation, the teacher is able to engage in a conversation with the student in the course of performance, providing feedback or asking critical questions. Many have suggested that in-action supervision is the ideal, occurring "in the trenches of the immediate dilemma."62 However, clinical educators must admit that while Schon's notion of having a conversation with the student might work in a seminar room or an architectural studio, it does not work in a setting such as the courtroom, where the student has to be "on" and is unable to have a conversation with the supervisor, as my student learned the hard way. ${ }^{63}$ There may be opportunities to have the occasional brief whispered conversation with a student, but this can hardly measure up to the dialogue proposed by Schon. ${ }^{64}$ Any legitimate re-

58 Id. at 62.

59 See Schon, Educating the Reflective Practitioner, supra note 17, at xi, 12.

60 See Mark N. Aaronson, Thinking Like a Fox: Four Overlapping Domains of Good Lawyering, 9 CLIN. L. Rev. 1, 10-11 (2002). Problem-solving is a methodical approach for preparing and organizing to do different tasks, with a heavy emphasis on the establishment and evaluation of explicit objectives. Decision-making describes the process that we use to reach a conclusion when we already have substantial information in hand. Practical judgment requires relying on hard techniques and information for making pivotal choices, weighing and prioritizing competing concerns in a manner that is relatively non-formulaic. Id.

61 See Neumann, supra note 18, at 405, citing SChon, Educating the Reflective Practitioner, supra note 17 , at xii.

62 See, e.g., Baker, supra note 5, at 55.

$63 \mathrm{Id}$. at $75 \mathrm{n} .284$ (acknowledging that in certain public performances, the opportunity for supervisory interaction is nonexistent).

64 See, e.g. Shalleck, supra note 39, at 123-33 (including a fictional trial transcript in which the student and the supervisor have several whispered conversations). See also Robert E. Jagger, Stetson: The First Public Defender Clinic, 30 Stetson L. Rev. 189, 205 (2000) 
flective conversation with the student would cause too much interference. Even Schon acknowledges that "reflection-in-action" operates in a "virtual world" between the supervisor and student and that there are practice situations in which it can be dangerous or inconvenient to "stop and think" in action. ${ }^{65}$

If this conversation cannot be had, what options does the clinical supervisor have for educating the student during the proceedings? One option is to collaborate with the student throughout the court appearance, fully playing the role of co-counsel.66 A second option is to temporarily model performance in an effort to offer an example of exemplary practice or at least expose them to a competent approach. ${ }^{67}$ The third option is to intervene by instructing the student to take a particular course of action. Each of these three educational choices necessarily involves some form of direct intervention by the supervisor that forces the student out of the primary representative role on behalf of the client. The fourth option, allowing the student to do it herself, does not have that result.

\section{The Difficulty With Ceding Educational Power in the Courtroom}

Perhaps because of the implicit recognition that this reflective conversation cannot occur in the midst of court proceedings, one of the greatest debates in clinical scholarship is the question of whether and under what circumstances a supervisor should intervene and model practice, thus restricting the student's direct representation of the client. ${ }^{68}$ Ironically, little guidance is given to new clinical supervisors about how to transition from a practice setting in which they have had primary responsibility for the handling of a case to ceding control

(sharing about an incident in which a clinical supervisor wired his student with a listening device and stood in the back of the courtroom with a transmitter whispering instructions).

65 Schon, The Reflective Practitioner, supra note 17, at 157, $277-79$ (discussing the limits of reflection-in-action in some practice situations, but noting that practitioners can seek to create new opportunities for it).

66 Some clinical supervisors have suggested that this is the ideal form of the relationship. See Frank S. Bloch, The Andragogical Basis of Clinical Legal Education, 35 V AND. L. Rev. 321, 346 (1982); Philip Gentry, Clients Don't Take Sabbaticals: The Indispensable InHouse Clinic and the Teaching of Empathy, 7 CLIN. L. Rev. 273, 278-79 (2000) (describing function of teacher in courtroom as co-counsel and guide for student).

67 Minna Kotkin describes three different kinds of role modeling by the supervisor: (1) one in which there is a gradual shifting of lawyer role from supervisor to student over the course of the clinical experience, (2) one in which the student and teacher assume different roles in different cases, and (3) extended role modeling. See Minna J. Kotkin, Reconsidering Role Assumption in Clinical Education, 19 N. MeX. L. Rev. 185 (1989), reprinted in part in Clinical Anthology Readings for Live-Client Clinics 80-82 (Alex J. Hurder \& Frank S. Bloch, et al., eds. 1997)

68 See Chavkin, supra note 20, at 1510 (reviewing range of clinical supervisors' views on the use of directive and non-directive supervision). See also James H. Stark, John Bauer \& James Papillo, Directiveness in Clinical Supervision, 3 B. U. Pub. Int. Law J. 35 (1993). 
to student attorneys under their supervision. ${ }^{69}$ A courtroom proceeding is a critical site for igniting the issues raised in that debate. The debate often tracks a related pedagogical question of whether the clinical supervisor should be directive or non-directive in the supervision of the student attorney.

Many clinical supervisors may feel uncomfortable with the notion that the courtroom, while a site for learning, is not an extension of their classroom such that they can continue to play a primary educational role during the course of the proceedings. Alternatively, they may not feel comfortable letting go of their past professional role as a practitioner in that forum. Especially for the new clinical supervisor who is overwhelmed by the job, directive, interventionist supervision can be seductive because it feels like the easiest, softest way. ${ }^{70}$ Accordingly, modeling, co-chairing, or frequent intervention may too easily be chosen as the only effective educational tools in the courtroom..$^{71}$ Armed with the comfort that they can use one of these tools "if necessary", clinical supervisors might be more likely to place too little emphasis on pre-appearance preparation and post-appearance reflective supervision and thus increase the likelihood that they will feel the need to intervene in the midst of proceedings. ${ }^{72}$

Inevitably, clinical supervisors face situations in court in which they feel compelled to take over responsibility for the representation in the absence of the ability to engage in a reflective dialogue with the student. Even the best-prepared of students can be thrown off guard or buckle completely when faced with a surprising situation. ${ }^{73}$ Likewise, an unexpected turn of events can leave students floundering with no tools to make an informed decision about how to proceed with the client's best interests in mind.

While some form of intervention by the clinical supervisor in such

69 See Justine A. Dunlap and Peter A. Joy, Reflection-in-Action: Designing New Clinical Teacher Training By Using Lessons Learned From New Clinical supervisors, 11 Clin. L. REv. 49, 49-50 (2004) (citing questionnaires from new clinical supervisors who attended the Clinical Legal Educator's Association New Clinical Teachers' Conferences). Many of these questionnaires indicated that new clinical supervisors have a primary concern about how to cede control over cases to students. Id. at 60-61.

70 See Dunlap \& Joy, supra note 69 , at 86.

71 See, e.g., Stark, et al., supra note 68 , at 57 (reviewing a number of justifications provided by clinical supervisors for why they might intervene during court proceedings). Stark includes an excerpt from a questionnaire submitted by a clinical supervisor which highlights this struggle: "I was a practicing lawyer for several years before coming to the clinic. I am used to handling cases myself, in my own way and in a timely fashion." $I d$. at 66.

72 As will be discussed infra, clinical supervisors can do a lot to prepare their students for a court appearance so that intervention by the clinical supervisor is less likely or necessary.

73 Seielstad, supra note 31 , at 206-07. 
situations might be appropriate or even necessary in some cases, I suspect that most clinicians lack a thoughtful framework for how to make this assessment. Clinical supervisors have often shared both formally and informally about their struggles in deciding whether to intervene in a court proceeding, but rarely does the scholarship draw from educational and psychological theory. ${ }^{74}$ Literature from these disciplines can be useful for clinicians to make a more informed choice in those moments when, as in court, a comprehensive reflective dialogue cannot occur with the student.

\section{Assessing the Merits of Education through Modeling In The Courtroom}

\section{(a) Risks to Educational Goals}

Modeling can be a powerful educational tool. Learning theorists have demonstrated that learning through imitation, or modeling, is an important method for the development of attitudes, beliefs, and performance skills. ${ }^{75}$ Modeling metacognitive and reflective skills to students can also be effective. ${ }^{76}$ For example, a clinician might demonstrate in supervision or in the classroom the framework for how to approach a client's problem when the solution is not readily apparent. The benefits of modeling are probably best experienced when done in a context where a reflective, interactive and open dialogue can take place.

Modeling in the courtroom, however, may be counterintuitive to the way in which clinical supervisors teach their students to problem solve through "ends-means thinking." 77 Students are novice practitioners. Unlike experienced practitioners, they lack a solid foundation

74 See Smith, supra note 46, at 732 (acknowledging that she intervened when her students were "rendered mute" by an in-court "criminal defense nightmare" when the judge decided to lock-up their client); George Critchlow, Professional Responsibility, Student Practice, and the Clinical Teacher's Duty to Intervene, 26 Gonz. L. REv. 415, 437-40 (1990/ 91) (discussing a situation in which a student forgot her closing argument and turned to the supervisor for help and engaging in a reflective assessment of whether intervention was appropriate under the circumstances). See generally Stark, et al., supra note 68 (including excerpts from questionnaires filled out by clinical supervisors regarding the tension between directive and non-directive supervision).

75 Malcolm Knowles, Elwood F. Holton III, \& Richard a. Swanson, The Adult Learner 103 (5th Ed. 1998) (describing the efficacy of modeling for adult learners).

76 How People Learn: Brain, Mind, Experience, and School 67 (M. Suzanne Donovan, John D. Bransford, and James W. Pellegrino, eds. 2000).

77 In what is now deemed a classic piece on clinical methodology, Anthony Amsterdam referred to "end-means thinking" as the process whereby "one starts with a factual situation presenting a problem or an opportunity and figures out the ways in which the problem might be solved or the opportunity might be realized." See Anthony G. Amsterdam, Clinical Legal Education - A 21st Century Perspective, 34 J. Legal Educ. 612, 614 (1984). 
of content knowledge and experience to draw from when faced with a problem to be solved. ${ }^{78}$ In the classroom and in supervision, clinical supervisors teach their students how a novice should go about trying to solve a problem: begin by reasoning backwards to a review of the client's goals and then quickly consider various options by which the client's goals might be met in the present situation, through a systematic and comprehensive evaluation of the consequences and feasibility of those options. ${ }^{79}$ Yet, as Gary Blasi has pointed out, expert practitioners use forward thinking to solve a problem, whereby they look at the whole situation and pick out familiar patterns to identify various options and make a decision, drawing on their past experiences. ${ }^{80}$ If the clinical supervisor is an expert in the field and/or forum, there is a strong likelihood that she will tacitly model forward reasoning, rather than the ends-means reasoning they want their students to practice.

Clinical supervisors should be cognizant that the power and impact of modeling can depend on several variables. For example, cultural variables might include the clinical supervisor's age, gender, race, socio-economic status, social power, ethic background, and intellectual and vocational status. ${ }^{81}$ Sometimes the combination of these variables will result in the student attorney placing little educational value on a clinical supervisor's modeling or intervention. For example, an older male student might be less inclined to model his female supervisor's practice in court. In other situations, these variables might result in the student feeling unable or conflicted in her ability to think critically about his supervisor's model or directive. For example, a young female student might have a more difficult time challenging the choices modeled by an older male clinical supervisor.

In the context of the courtroom, modeling and directive intervention are tools that, if grasped too easily, can seriously undermine students' ability to learn and develop content knowledge and professional skills. For a clinical supervisor to step into a more primary representative role, either implicitly or explicitly, is counterintuitive to the andragogical principle that experience is the richest

78 M. Suzanne Donovan, et al., supra note 76 , at 31 .

79 Amsterdam contends that "by reasoning backwards from goals, by mapping the various roads that might be taken to each goal, by proceeding backward step by step along each road and asking what steps have to be taken before each following step can be taken, one comes at least to have some well-advised basis for answering the question ..." Amsterdam, supra note 77 , at 614 .

80 See Gary Blasi, What Lawyers Know: Lawyering Expertise, Cognitive Science, and the Functions of Theory, 45 J. LegAL Educ. 313, 345-46 (1995). See also Mark Neal Aaronson, We Ask You to Consider: Learning About Practical Judgment in Lawyering, 4 CliN. L. REv. 247, 293-95 (1998) (describing the differences between backward reasoning of a novice and forward reasoning of an expert).

81 Knowles, et al, supra note 75 , at 40 . 
resource for adults' learning. ${ }^{82}$ As the adage goes, knowledge earned is better than knowledge learned. In court (as well as in other practice settings), "lawyers must choose a course of action, choose and choose again, witness the consequences of their choices, and pay the piper intellectually and emotionally, if not financially." 83

Donald Schon asserts that an effective professional reflects-in-action. ${ }^{84}$ But what does this mean in practice? Schon suggests that the professional must have a "conversation with the situation" - experimenting with how the situation responds, generating hypotheses and testing them. ${ }^{85}$ The clinical supervisor's role in this process is bestsuited by allowing the student attorney to engage in that conversation by herself, allowing the student to struggle through it, and experience it, without intervention. The student must respond to the situation internally, asking himself to hypothesize about the most likely consequences of a range of actions he could take. While this relative isolation in the moment might produce anxiety in the student, the student must experience the struggle and the moment of trying to determine how to resolve it. Such a process is consistent with adult learning theory, which places a strong emphasis on the value of self-directed, experiential learning by making decisions, facing the consequences of those decisions, and managing the outcomes. ${ }^{86}$ Once the clinical supervisor steps into the representative role, the student misses the opportunity to reflect on what it feels like, for the first time, to take responsibility for one's own learning and simultaneously take responsibility for a client's case. ${ }^{87}$

If the clinical supervisor promised self-directed learning and then turns around and strips the student of the agency to do so, then the

82 Id.

83 Shalleck, supra note 39, at 164, citing Anthony G. Amsterdam, The Lawyering Revolution and Legal Education 16 (1985) (unpublished paper presented at the Cambridge lectures, July 15, 1985).

84 Schon, The Reflective Practitioner, supra note 17, at 50.

85 Id. at $49-69,128-67$.

86 See Bloch, supra note 66 , at $328-29$ (reviewing literature on adult learning theory to support clinical methodology).

87 Phillip Schrag and Michael Meltsner point out that unlike any other law school professors, non-directive clinical supervisors provide students with an opportunity to ask themselves some important questions: "To what extent do I feel comfortable with myself as a lawyer? Am I self-sustaining or do I make unreasonable demands on others for support and satisfaction? To what extent do I feel free to satisfy my own goals and needs with appropriate aggressiveness? Do I too often (or not often enough) depend on others? How do feelings about clients affect my conduct as a professional? My nonprofessional life? To what extent can I engage in self-criticism or peer criticism without exaggerated loss of selfesteem or undue defensiveness?" Phillip G. Schrag \& Michael Meltsner, Report from a CLEPR Colony, Reprinted in Reflections on Clinical Legal Education 56 (1998). 
trust in such an educational contract will have been destroyed. ${ }^{88}$ One of the foundational principles of adult learning theory is that adults view themselves as being responsible for their own decisions and have a need to be seen by others and treated by others as being capable of self-direction. ${ }^{89}$ Clinical supervisors risk robbing their students of the ownership of learning firsthand from a painful professional moment and the opportunity to consider why it happened, what could have been done to prevent it, and what options existed for reacting to it in the moment. ${ }^{90}$ It also disrupts the sense that this is the student's client, not the clinical supervisor's. It is very possible that the damage to the student's professional self-esteem will be worse if she is not permitted to try to rectify the situation herself. Indeed, there is a danger that the student will more readily hand over the reins in the future, rather than learn to take greater responsibility of her cases. ${ }^{91}$ If the clinical supervisor is too quick to jump in and "save" the student attorney, the student may consciously or unconsciously slip into an acceptance that the supervisor or some other senior attorney will always be there.

It is essential is that the student not miss out on the opportunity to practice the essential skill of decision-making in the moment of a courtroom appearance. No matter what the issue, attorneys are continuously confronted with problem-solving opportunities during a court appearance. ${ }^{92}$ This skill can really only be learned through trial and error and experimentation with various choices for action. ${ }^{93}$ As one student has noted:

One must experience what it is like to be a criminal defense attorney in order for one to have the lasting impression needed to be a

88 See Stephen D. Brookfield, Developing Critical Thinkers: Challenging Adults to Explore Alternative Ways of Thinking and Acting 91 (1987). Brookfield warns that it is "inconsistent and destructive of trust" for a facilitator of adult learning to say that he believes in self-directed learning and then to insist that learners follow the facilitator's instructions or model.

89 See Knowles, et al., supra note 75, at 65.

90 See Shalleck, supra note 39, at 154 (noting that delaying intervention until after the student has acted allows the student to "own" the experience more deeply and thus have a more powerful basis for later reflection and understanding).

91 George Critchlow warned that the student may feel demoralized and inadequate and thus become overly dependent on the clinical supervisor in the future, the opposite result of what clinical supervisors intend for student attorneys in a clinical setting. See Critchlow, supra note 74 , at 416 .

92 See Shalleck, supra note 39, at 164, quoting Anthony G. Amsterdam, The Lawyering Revolution and Legal Education 16 (unpublished paper presented at the Cambridge Lectures, July 15, 1985). Amsterdam notes that "day after day, lawyers must choose a course of action, choose and choose again, witness the consequences of their choices, and pay the piper intellectually and emotionally, if not financially." Id.

93 See Paul Brest \& Linda Krieger, On Teaching Professional Judgment, 69 WASH. L. REV. 527, 559 (1994). 
skilled trial attorney. Feelings of uncertainty, confusion and sheer inexperience can only be overcome when one is forced to make quick judgment calls and quick decisions. The real learning begins when you are confronted with the consequences of those hasty decisions. Sometimes the consequences are positive, and sometimes they are negative. It is the thought process of sorting out all this data that brings lasting lessons to a student involved in a clinical program. I find myself reevaluating my performance and rethinking better ways to make informed decisions. ${ }^{94}$

Ironically, a student attorney under the close supervision of a clinical supervisor is more likely to be able to face unexpected situations in the courtroom than many new attorneys who have not had exposure to clinical education. Yet, those new attorneys would likely admit that some of their greatest learning experiences came from the mistakes that they made during their first few years out of law school.

\section{(b) Risks to Client Interests}

While clinical educators have long sought to improve the nature of legal education, they have created their programs in an effort to provide more competent legal services to impoverished communities of clients who might otherwise go unrepresented. Clinicians rightly have a strong interest in protecting clinic clients, but taking over the representation during a court proceeding is not necessarily the best way to do that. Directive intervention or modeling in the courtroom can have a devastating impact on the student's representative role as seen through the eyes of other individuals present. The client might question the abilities of the student attorney and become confused as to who is ultimately responsible for the case. ${ }^{95}$ Opposing counsel might view it as a sign of weakness and attempt to take advantage of the student going forward in the proceedings. The judge might also resent the "tag team" effect of both the supervisor and student attorney or doubt the student attorney's actions and thus attempt to play a stronger role in "mentoring" the student who appears before her.

Clinical supervisors who too easily grasp co-chairing, modeling or direct intervention with the student as their primary educational tools might justify their decision by arguing that as experts in the profession, they should not hide that expertise but instead allow it to benefit

94 M. Pinguelo, The Struggle Between Legal Theory and Practice: One Law Student's Effort to Maintain the 'Proper' Balance, 1998 B.Y.U. Educ. \& L.J. 173, 192.

95 See Critchlow, supra note 74, at 416. Jennifer Howard, a former clinic student at the Columbus School of Law, discussed her concerns about the constraints placed on her relationship with her client because of the presence of and occasional intervention by her supervisor. See Jennifer Howard, Learning to "Think Like a Lawyer" Through Experience, 2 Clin. L. REv. 167, 186-92 (1995). 
the client. ${ }^{96}$ But the clinical supervisor must check her professional ego at the door of the courtroom when supervising a student attorney for there is the possibility that the clinical supervisor's performance, despite more years of experience, will ultimately be less advantageous than had the student been given the opportunity to struggle through the performance. Often the student has far more knowledge about the facts of the case, as well as the particular goals of the client. The clinical supervisor's ability to step in and make an effective argument assumes that the clinical supervisor is really in the best position to "know" the "right" way to handle the situation. Even the most experienced clinical supervisors will face situations in the courtroom where neither they, nor the student, know the best way to proceed. The notion that a clinical supervisor's experience makes her professional skills necessarily superior to those of the student is antithetical to the realist notion that there is rarely a "right" or "wrong" way to represent a client. Moreover, there are times where students can "infuse the proceedings in which they participate with a freshness and a sense of commitment that is sometimes lacking" even in the best of clinical supervisors. ${ }^{97}$ It may well be that there are times in which the clinician's "insider" status, just as can often happen with opposing counsel, dilutes the potential creativity of the representation. ${ }^{98}$ Alternatively, it is conceivable that there might be times when students' naiveté may work in their favor because a more experienced attorney might not be given the same amount of leeway by a judge or opposing counsel.

Critics might legitimately argue that the value to the student of this solo experience can only go so far until it crosses a line and takes too much of a toll on the client's case. ${ }^{99}$ Every clinical supervisor will have to make an individual assessment of where to draw that line and it is that decision which is perhaps the most difficult one for a clinical supervisor to make. ${ }^{100}$ But I suspect that many clinical supervisors

96 See, e.g., Baker, supra note 5, at 67.

97 See Judge Greene, supra note 48 , at 278 . o

98 See Morris D. Bernstein, Mr. St. Clair's Case, 35 Tulsa L. J. 295, 314 (2000) (reflecting on "insider" status of opposing counsel and impact on client's case). See also Laurie Morin and Louise Howells, The Reflective Judgment Project, 9 Clin. L. Rev. 623, 630 (2003) (discussing how in some cases, an expert's cognitive biases in favor of familiar schema could cause the expert to misjudge the problem).

99 Having reviewed the Rules of Professional Conduct and student practice rules from various jurisdictions, George Critchlow suggests that the minimum standard for intervention is where the supervisor must take "remedial action to avoid or mitigate the consequences of conduct which would violate the Rules of Professional Conduct." Critchlow, supra note 74, at 426 . Certainly there may be times when the student has not had sufficient time to prepare and develop, such that the clinical supervisor will be forced to play a more active role in the proceedings.

100 See Peter A. Joy, The Law School Clinic as a Model Ethical Law Office, $30 \mathrm{WM}$. 
allow less slack than is really necessary and might be surprised to see their students "redeem themselves" if given the freedom to do so. ${ }^{101}$ In fact, judges appear to feel confident about student attorneys' abilities to meet professional performance standards in court. ${ }^{102}$ One judge has pointed out that a well-supervised student who goes it alone in the courtroom is likely to be as competent or even more competent than a newly-admitted lawyer. ${ }^{103}$ Clinical supervisors might reflect that there are very few actions in the representation of clients that are truly irreversible or uncorrectable. And there is wide variety in how lawyers would choose to respond to any given situation. If that is the case, then it follows that there is room for students to experiment with those choices in the courtroom while at the same time not coming close to the line of endangering the client's case.

\section{Preparing Students For Self-Directed Practice In Court}

Some students would surely resent what they might view as a "hands off" approach and worry that the supervisor is "hiding the ball" when they are faced with a critical moment in court where they have to make a fast decision that will have real consequences for the client. ${ }^{104}$ Others may fear it or experience considerable anxiety. ${ }^{105}$

Mitchell L. Rev. 35, 49 (2003) (describing the tension between allowing the student the educational opportunity to be in role and the responsibility to provide the client with quality legal representation). See also Critchlow, supra note 74, at 419; Stark, et al., supra note 68 , at 35 .

101 Judge Shirley R. Levittan of the Criminal Court of the City of New York shared a story about one student practitioner who, at his first appearance before her, could barely frame a question and the Judge's feeling that "while I knew his client would survive the ordeal, I was not sure that the student would." See Judge Levittan, supra note 16, at 285.

102 For example, in questionnaires received from 49 judges before whom clinic students had appeared, the judges observed that clinic students were usually as well prepared as the average practitioner and $25 \%$ considered students better prepared, this despite the fact that in the majority of those jurisdictions, the supervisor was only sometimes or never present with the student in court. See Judge Alvin B. Rubin, $A$ View from the Bench, in Clinical Education for the Law Student: Legal Education in a Service Setting 252 (Working Papers Prepared for CLEPR National Conference, Buck Hill Falls, PA 1973). The students' oral arguments and direct examinations were considered average by $75 \%$ of the judges ( $25 \%$ found the students' performance inferior). Id. at 253 . A majority (60\%) also found students' cross-examinations average ( $40 \%$ found their performance inferior). Id. 47 of 49 judges believed that the students provided competent representation to their clients. Id. at 251-52.

103 See Judge Wenke, supra note 39, at 299.

104 See Schrag \& Meltsner, "Scenes from a Clinic," reprinted in Reflections on Clinical Legal Education 97 (1998).

105 Jennifer Howard, a former student of Margaret Barry's at the Columbus School of Law, wrote candidly about the anxiety and frustration that she experienced in clinic in the face of "non-directive" supervision, though these emotions seem to have resulted from incidents that occurred at the beginning of her clinical experience and did not involve any court appearances. See generally Howard, supra note 95. In addition, Howard admits that her anxiety stemmed from her inability to evaluate her own progress and the lack of evalu- 
To avoid these concerns, the clinical supervisor would be wise to broach a discussion with students at the outset of the course about her supervisory methodology, goals, and reasons why this methodology has been chosen over others. ${ }^{106}$ In addition, the clinical supervisor should clearly revisit the theoretical basis for self-directed practice during preparation for the court appearance. Clinicians should openly encourage students to move beyond thinking of their supervisor's role in the courtroom as a safety net into which they can easily fall if faced with a difficult dilemma. They might also discuss how students can expect to experience anxiety in the courtroom and ask them to think about the line between healthy motivational anxiety and that which debilitates and paralyzes. ${ }^{107}$ Engaging in these discussions upfront increases the likelihood that a student will not feel unsafe with this supervisory approach. ${ }^{108}$ Rather, the student will more likely be able to access the tools honed during that preparation time and move forward smoothly in applying and drawing upon them in the courtroom.

Ultimately, students should understand that the clinical supervisor's decision about whether to intervene in a student's court appearance should never be treated as a "one size fits all" approach, but instead must be tailored to the specific situation and student. ${ }^{109}$ While adult learning theorists advocate the need for experiential, self-directed learning, they also recognize that adult education must make optimal provision for differences in style, time, place, and pace of learning. ${ }^{110}$ Certainly all adults do not have the full capacity for selfdirected learning in every situation. ${ }^{111}$ Different students will fall into

ation received from her supervisor. Id. at 181-86. See also Rader, supra note 42, at 311-13 (discussing how his doubts about his abilities to represent his client frightened him and often made him feel angry with his supervisor).

106 I begin each year with an open discussion of my supervisory method, laying out my expectations for the student as well as for myself, and frequently revisit the topic during the year.

107 As Kenneth Kreiling has noted, "The gaps between knowledge and skill, on the one hand, and role demands on the other, contribute to a high level of anxiety in most students. The anxiety, if kept within reasonable bounds, is a powerful motivator." Kenneth R. Kreiling, Clinical Education and Lawyering Competency: The Process of Learning to Learn from Experience Through Properly Structured Clinical Supervision, 40 MD. L. REv. 284, 287-88 (1981).

108 A.H. Maslow and other clinical psychologists have emphasized that growth and learning cannot occur if the individual is crippled by fear and does not feel safe enough to embrace the educational process. See Knowles, et al., supra note 75, at 47 (describing the contributions of clinical psychologists on the development of adult learning theory.

109 Thus, I reject the broad proposition that "every intervention is a failure of supervision." Cf. Chavkin, supra note 20, at 1542.

110 Knowles, et al, supra note 75, at 40 (summarizing the foundational principles of adult learning theory). See also Shalleck, supra note 39, at 173 (noting that "[s]upervision requires an enormous amount of individual diagnosis").

111 Knowles, et al., supra note 75, at 136. 
different places along a cognitive developmental continuum and thus, their problem-solving and critical judgment skills will differ. ${ }^{112}$ The capacity for self-directed learning is situational and it is the clinical supervisor's job to constantly assess and consider whether intervention is appropriate. While the clinical supervisor should take into account the student attorney's level of frustration or intimidation, those emotional responses should be weighed against several other factors, such as the students' learning style and capabilities, the timing of the case and the amount of preparation permitted, ethical implications, as well the impact of other participants in the courtroom. ${ }^{113}$ The clinical supervisor, like any good teacher, should talk with the student about what would offer the best educational experience for that particular student at that moment, while at the same time balancing the needs of the client and the emotional comfort of the student.114 Mindful of competency standards throughout the proceedings, the clinical supervisor should seek the input of the student and together negotiate the role she will play if the student's performance raises clear ethical or fiduciary concerns. ${ }^{115}$

\section{Education and Preparation of the Student Outside THE COURTROOM}

Clinical supervisors can enrich the opportunities for their students to take primary responsibility during a court appearance and

112 See, e.g., Morin \& Howells, supra note 80, at 640-44 (reviewing educational psychologists' stages of reflective thinking ability); Aaronson, supra note 80, at 301. See also, Patricia M. King \& Karen Strohm Kitchener, Developing Reflective Judgment: Understanding and Promoting Intellectual Growth and Critical Thinking in AdOLESCENTS AND Adults (1994).

113 For example, adults who feel more competence in the subject matter and a low need for dependence will be much more independent as learners than those who have little competence and prefer dependency. See Knowles, et al, supra note 75, at 145 . Knowles refers to Grow's Stages of Learning Autonomy to point out that different adults are at different stages of learning autonomy and thus, an ability to be self-directing. For example, at Stage 1, the student is dependent and the teacher will have more authority, coaching with immediate feedback and drills and using informal lectures. But by Stage 4 , the student is self-directed and the teacher is more of a consultant and delegator, which is more appropriate for internship and actual work settings. Id. at 137.

114 As a result of my work in the Disability Advocacy Clinic and our representation of parents of children with special needs, I have come to recognize that it is absurd for me to support the view that each child has individualized learning styles and needs, but to then ignore that this continues into adulthood. Accordingly, it is incumbent on clinical professors to expose themselves to the rich research and scholarship on adult learning theory in an effort to inform themselves of the variety of pedagogical approaches to supervising a student attorney.

115 See Critchlow, supra note 74, at 424-25 (discussing Rules of Professional Conduct implicated in supervision of law students by clinical professors, noting that the clinical supervisor must take remedial action to avoid or mitigate consequences of conduct which would violate the Rules). 
lessen their inclination for using directive educational tools by placing more emphasis on pre- and post-appearance preparation and reflection, while at the same time incorporating a flexible and nuanced application of adult learning theories. For students, courtroom practice holds significant mystery. ${ }^{116}$ Even those students who have had a solid introduction to legal realism and the indeterminacy of the law in the courtroom are genuinely shocked when they learn first-hand the extent to which unwritten rules and local customs - including relationships, power dynamics, and shared understandings between certain participants in the legal process - play a powerful role in the American judicial system. ${ }^{117}$ Students also express surprise at the number of situations that arise in a court proceeding for which there are no easy or apparent answers. This shock can often lead to heightened anxiety and increased difficulty accessing the tools that they have honed prior to the appearance. The clinical supervisor's goal should be to build a developmental path of learning for the student attorney that can result in a more confident and successful experience without the need for directive intervention or modeling by the supervisor. ${ }^{118}$

As will be discussed below, clinical supervisors can make use of simulated exercises and analytical, reflective discussions outside of the courtroom to control the various elements and provide a more focused educational experience in anticipation of the indeterminacies of the live courtroom experience.119 Prior to and after the courtroom appearance, the clinical supervisor can engage the student attorney in a rich examination of the various ways that indeterminacy can play out in the courtroom. While students increase their awareness as to the complexity of representing a client in a court proceeding, clinicians can also help their students to understand that they must take the responsibility to make judgments and draw conclusions that are in the best interest of the client. What most students fail to grasp until they have had the opportunity to experiment with it in action is the notion that as lawyers, they can exercise extraordinary discretionary power over the substantive content of legal rules. ${ }^{120}$ Despite the reach

116 See Neumann, supra note 18 , at 408.

117 Seielstad, supra note 31, at 129.

118 This pre-appearance educational development is intended to address much of the anxieties about the "newness" of the courtroom experience for the student attorney. Front-loading this work provides more opportunity for direct experiential learning by the student than modeling or co-counseling might. Cf. Gentry, supra note 66, at 279-80.

119 See Schon, The Reflective Practitioner, supra note 17, at 157-62 (discussing the creation of "virtual worlds" of "reflection-in- action" for educating practitioners in a variety of professions).

120 See Wilkins, supra note 47 , at 470 (discussing the extent to which indeterminacy arguments of legal realists impact the construction of rules of professional conduct and regulation of the legal profession). 
of the legal realism and critical legal studies movements into the academic world of the law, much of today's law school experience continues to impress upon students the notion that there are normative boundaries that are easy to read and easy to follow. An unfortunate result is that students and young attorneys lack a sense of agency or power to advocate on behalf of their clients. The clinical educator can challenge students to question these normative assumptions and view themselves as effective problem-solving agents.

\section{A. Pre-Court Preparation and Development}

While basic skills training and a comfort level with evidentiary and procedural rules are essential, clinical supervisors must elevate the value of learning to think critically and practicing reflective judgment as fundamental components of preparation for a court appearance. ${ }^{121}$ I have since realized that my failure of supervision in the case described at the beginning of the article was not that I didn't intervene, but that I didn't adequately prepare the students to effectively deal with an unexpected situation or one in which they realized that they had made a mistake and must resolve it as best as possible. ${ }^{122}$ Too often, clinical supervisors get caught up in the "to do" lists in the days leading up to an appearance and fail to incorporate time for the student to rise above the logistics and gain a more profound, overall perspective of the case and its place in the legal setting.

Just as doctrinal professors might be criticized for placing too much emphasis on substantive law, clinical supervisors might be critiqued for focusing too much of their supervision and class time on skills training. And yet the need for professional judgment is what transcends all other skills for a practicing lawyer. ${ }^{123}$ If given the

121 Indeed, because critical thinking is so essential to the skills of any lawyer, nonclinical law professors should seek to incorporate more critical thinking exercises into their curriculums. As noted in the most recent draft of the Clinical Legal Education's Best Practices Project, law schools should not train students simply "to perform mechanical lawyering tasks" but instead recognize that "[t]here is so much more to the law, even for the practice of law, than that: issues such as the social functions of law, the factors that influence legal development, patterns of change, the interaction of law with other forms of social control such as religion, and, of course, the relationship of law and ethics." See BEst Practices for Legal Education, supra note 27 at 14, citing Alan Watson, Legal Education Reform: Modest Suggestions, 51 J. Legal Educ. 91, 93 (2001).

122 In retrospect, no amount of preparation and development in a three-week period of time at the outset of the semester could have placed my students in a position in which I would have felt comfortable with their ability to try the case without my intervention.

123 D. Don Welch argues that being able to understand "what's going on" is a critical element that law students must master in honing their professional judgment and he notes that too many law professors view their job as teaching doctrine and theory, rather than contributing to the development of professional identity, judgment and values. See D. Don Welch, "What's Going On?" in the Law School Curriculum, 41 Hous. L. REv. 1607, 1609- 
chance to do so, student attorneys can spend their preparation time honing their critical thinking skills by becoming aware of the assumptions and biases that underlie their own actions, as well as those of others. ${ }^{124}$ Students will also give greater consideration to the context in which actions and ideas are generated and played out. ${ }^{125}$ And perhaps most importantly, students will resist the temptation to gravitate towards quick-fix solutions or attempting to find the "right answer", and instead open their minds to identifying the range of choices that arise in a case and the alternative ways of solving problems. ${ }^{126}$

Clinical supervisors usually are quite adept at incorporating strong skills training into the classroom component of their programs, but the breadth of that skills training varies. While traditional introduction to trial practice skills are important, problem-solving and critical thinking skills too easily fall by the wayside, especially when a trial is fast-approaching and the student has much to do to get up to speed on the case. Students should not wait until the problem-solving moment is at hand during the proceedings to begin to practice these skills.

As mentioned earlier, students often confront situations in which their interpretation of the hierarchical position of the judge (or even opposing counsel) has an impact on the choices that they make in the courtroom. In an effort to combat those views, the clinical supervisor might require the student attorney to visit the courtroom in advance of the appearance. ${ }^{127}$ In addition to learning valuable information about the judge's administrative style and courtroom expectations, the student attorney can also be asked to consider the physical layout of the courtroom, especially the height differentials of the judge, jury, witnesses, lawyers, and clients. ${ }^{128}$ The student should be encouraged to reflect on the differences between this courtroom and other forums in which they have appeared, especially administrative proceedings. And, the clinical supervisor can challenge the student to think about

10 (2005).

124 BROOKFIEld, supra note 88, at ix.

125 Id.

126 Id.

127 I recognize that this exercise may be unworkable for clinics that practice in administrative forums in which hearings are closed to the public. However, the exercise can be modified by asking current students and/or former students to share their experiences in the forum and provide some insight into what can be expected. I find that having other students relay this information can be far more powerful than if it were to come from me because students will often focus on different factor than I might have chosen to discuss.

128 Andrea Seielstad refers to this kind of exercise as the "ethnographic method", whereby students "act more as anthropologists, listening, observing, participating, and synthesizing important verbal and nonverbal cues from its participants." Seielstad, supra note 31 , at 168 . 
what, if anything, the student and/or client can do to surmount those geographic obstacles in an effort to feel more in control of the proceedings. The result of these exercises is that the student gains a more experienced and nuanced view of the forum, while at the same time obtaining valuable information that can assist the student attorney in counseling his client and strategizing for the client's benefit. ${ }^{129}$

In preparing to appear in a particular forum, clinical educators should challenge their students to think critically about the professional (or unprofessional) conduct of other lawyers in the courthouse. Clinicians might ask their students to observe the professional demeanor of the participants in court and reflect upon what it means to act as an ethical, professional lawyer in the courtroom. The students should identify what factors to assess in making drawing their conclusions. For example, did they consider the professional's appearance, what he said, how he said it, or how the professional related to others? Reflecting on these questions can prevent the student from unconsciously adopting the behaviors of others as "professional conduct."

After having observed the courtroom, the clinical supervisor might have a collective discussion with the clinic students about the various ways in which judicial conduct can impact upon the proceedings. Students can readily offer examples of evidentiary or procedural rulings, but the clinical supervisor should press them to think beyond that realm as well. The students should be challenged to consider, as a group, how they might respond if a judge acts in an unexpected or surprising manner during one of these situations. For example, how would she react if the judge makes prejudicial comments to or about her client or if the judge makes an incorrect procedural ruling? Allowing other students to participate in the brainstorming can open up the variety of scenarios, as well as the choices for responding to those scenarios. The clinical supervisor can then guide the discussion into an evaluation of the choices available based on likely consequences and by re-visiting the client's goals for the case. When mooting arguments, the clinical supervisor may take on a variety of personas as the judge, providing the student with the opportunity to practice that internal evaluation in the hopes that it will feel more comfortable and less surprising when the real moment is at hand.

Another useful exercise is to have the student articulate his assumptions and/or expectations about an upcoming court appearance and then engage in a critical analysis of the validity of those assumptions. Although most student attorneys are young adults, they will have accumulated enough experiences that they will unconsciously

129 Id. at $185-86$. 
make assumptions and fail to consider viable alternatives as a result of those experiences. ${ }^{130}$ In one-on-one or group discussions, clinical supervisors should ask their students to identify their assumptions and expectations about the judge, including personality, style, cultural affiliations, and the impact of these variables on the proceedings. Other areas for discussion might include the students' assumptions about the procedural requirements, the expectations of court personnel, the role of opposing counsel and the dynamics that will occur, and the client's position in the proceedings. ${ }^{131}$ The clinician can encourage the students to think about the genesis of those assumptions, such as television or movies, portrayals of trials in the media, or "war stories" shared by practitioners. ${ }^{132}$ Use of the group setting for this discussion enlists the support of the other clinic students to help the student attorney (and themselves) examine the accuracy and validity of those assumptions. By engaging in this discussion prior to the court appearance, it offers the student attorney an opportunity to visualize the proceedings and consider whether there are assumptions she has made, either consciously or unconsciously, that might need to be revisited. Similarly, the student will likely identify new issues or factors to consider in her preparation that might otherwise have gone overlooked.

Many students are unprepared for the extent to which judicial discretion and unwritten rules or customs play a role in the courtroom proceedings. ${ }^{133}$ No matter how much clinical supervisors attempt to prepare them, the instructions will inevitably be incomplete. ${ }^{134}$ When faced with a situation that was not "in the book", be it practice manual or casebook, law students may feel great discomfort with the necessary improvisation and testing for the situation. ${ }^{135}$ Teaching the students the value, as well as the limits, of prediction can be an important pre-appearance exercise. Despite the indeterminacy of the courtroom, the clinical supervisor can still do much to prepare the student attorney about general practices and the culture of the forum, while at

130 See Knowles, et al., supra note 75 , at 66.

131 This "assumptions" exercise can dovetail nicely with related discussions of multicultural and cross-cultural lawyering. See, e.g. Susan Bryant, The Five Habits: Building CrossCultural Competence in Lawyering, 8 ChIN. L. Rev. 33 (2001); Carwina Weng, Multicultural Lawyering: Teaching Psychology to Develop Cultural Self-Awareness, 11 CLIN. L. REv. 369 (2005).

132 A related exercise for the classroom might include the review of a selection of newspaper articles, movie or television clips, or novels to consider how the courtroom and the characters within are portrayed in our culture, followed by an examination of the accuracy of those portrayals and the impact that it has on the assumptions that students, as well as their clients, might carry into these proceedings.

133 Seielstad, supra note 31, at 129.

134 Schon, Educating the Reflective Practitioner, supra note 17, at 103.

135 Id. at 5. 
the same time encouraging the student to ask questions about those practices and not grasp on to them in a desperate need to gain the comfort of being "in the know."

It is impossible to engage in enough preparation with a student attorney such that he or she is as well-versed as a regular practitioner in the forum in which they are about to appear. The clinical supervisor can direct the student to identify and investigate resources for learning more about the legal culture of the forum, such as common unwritten rules of courtroom decorum or procedure. Lawyers who practice over a long period of time in a particular forum tend to develop common understandings of appropriate behavior, sometimes regardless of the impact that it might have on their clients. ${ }^{136}$ Students might consider how they can find more information about these unwritten rules, such as observing court proceedings, talking to court personnel and local practitioners, or consulting local bar resources. ${ }^{137}$ While most students might feel compelled to grasp at these unwritten rules for normative guidance, the clinical supervisor can also help the student attorney to consider the merits of following such rules in any given case. ${ }^{138}$ Similarly, students can inform their ability to predict the consequences of any number of choices made in the context of representation by consulting local bar journals about jury or settlement awards, online sources with judicial rulings and opinions, or by having conversations with local practitioners about how opposing counsel tends to operate in certain situations. On the other hand, prediction is an incomplete response to indeterminacy and student attorneys should always be encouraged to think about different variables that might impact on those predictions, as well as alternative choices if the predictions are incorrect.

Teaching students how to resolve unexpected problems, especially those in which there is not an apparent "best" solution identifiable by the student, should be a critical step in pre-court appearance preparation and should be revisited routinely. Many students, like their clients, beg for the clinical supervisor to tell them how things will go in the courtroom, to predict the outcome and all the various events along the way, or to tell them the best course of action for their cli-

136 Wilkins, supra note 47 , at $488-89$.

137 Seielstad, supra note 31, at 198.

138 Many clinical supervisors can likely cite examples in their cases in which their students have blindly followed the advice of a local practitioner or courthouse employee because of the assumed cloak of authenticity such advice might carry. For example, a student might fail to follow a written procedural rule because an employee in the clerk's office has told the student that the rule isn't followed and only later does the student realize that following the rule and arguing for its enforcement might have been more beneficial for the client. 
ent. ${ }^{139}$ Students are often surprised when the clinical supervisor acknowledges that he doesn't have all the answers. But what separates the experienced practitioner from the novice is that the experienced practitioner is more likely to have developed a process for solving problems that are unanticipated or that must be resolved even in the face of uncertainties. ${ }^{140}$ With experience, lawyers learn to assess a number of factors and then make a reasoned prediction about the outcome of a case. Even without that experience, clinical supervisors can assuage their students' anxiety by teaching them to identify and consider factors that will affect the outcome, to assess the weight due each of those factors, and to come to a conclusion about the best action for their client. ${ }^{141}$

Prior to a court appearance, the clinical supervisor can employ exercises in the classroom in which students are forced to identify and resolve problems "in the moment" by developing a habit of exercising reflective judgment. Unlike most of law school, the courtroom is one of many sites in which a practitioner may be presented with an "illstructured" that requires the exercise of reflective judgment. "Illstructured" problems are ones in which the lawyer does not have complete knowledge of all the relevant facts or options, has not faced the situation before, and thus cannot resolve the problem with an easilyidentifiable or certain solution. ${ }^{142}$ By offering pre-appearance opportunities for students to face ill-structured problems and develop a process for resolving them, clinicians can teach students the art of building a repertoire for practice when these problems arise in their clients' cases. ${ }^{143}$

After presenting an ill-structured problem, the clinical educator

139 In fact, as a new clinical supervisor, I was no different from my students and found myself wanting the more experienced clinical supervisors with whom I worked to predict for me how things would go with the students in various courtroom experiences.

140 Patricia King and Karen Kitchener present data indicating that most graduate students operate at a "quasi-reflective thinking" stage, characterized by the ability to recognize that some problems are ill-structured and uncertain, but that they do not understand how to use available evidence to draw a reasoned conclusion or to justify their beliefs. See KING \& KITCHNER, supra note 112, at 58, 171-73.

141 Wilkins, supra note 47 , at $488-91$. For example, Wilkins notes that the substantive rules are often too indeterminate to support reasonable predictions and legal outcomes are highly contingent on the actions of other players, and in some cases, those players might not be identifiable until the parties show up at the courthouse.

142 King and Kitchener refer to the "ill-structured problem" as one which cannot be described with a high degree of completeness, cannot be resolved with a high degree of certainty, and about which experts often disagree as to the best solution, even when the problem can be considered solved. See KING AND Kitchener, supra note 112, at 11.

143 Laurie Morin and Louise Howells have written about their experiment in using King and Kitchener's theories to better understand how to help their students work through illstructured problems in their clinic. See generally Morin and Howells, supra note 98. 
can introduce the first step in developing critical thinking skills: ask the students to identify the problem(s) in the context of a situation. ${ }^{144}$ The clinician can then lead a discussion with the students about which problems they identified and which ones they ignored. The students might consider the impediments to critical thinking and problem identification in the situation, such as formulating inaccurate or incomplete assumptions based on information from questionable sources such as the media, stereotypes, fears, or one's own previous experiences. ${ }^{145}$

After the students identify the problem(s), the clinician should encourage a student to engage in a "slow motion" process, wherein the student goes through the following series of analytic steps: revisiting the client's goals and other interests at stake, (2) considering whether it is a long or short-term problem that needs immediate action, (3) evaluating what information the student has and what might still be needed to make an informed decision, (4) generating a list of options for resolution, (5) weighing each by consideration of pros/ cons, possible consequences, feasibility, and achievement of client's ultimate goals for the case, and (6) making a conclusion about how to proceed. ${ }^{146}$ After deciding on a path for resolution, other students in the class can collectively reflect with the student about how and why the problem arose, whether the student could have prevented it from occurring, what obstacles or concerns arose, what other facts the student needed, what assumptions the student made and whether those assumptions were well-founded, and identification of further resources for understanding the problem. ${ }^{147}$

These exercises not only provide a framework for problem-solving, but also build a comfort base from which the student can draw once in the courtroom and faced with an unexpected turn of events. As the time draws near for a court appearance, the clinical supervisor can challenge the student attorney to demonstrate this problem-solving approach in a simulated setting. For example, the clinician might play the role of the judge during a piece of the student's presentation of the case and raise unexpected issues with the student, requiring an immediate response and resolution. Afterwards, the class can reflect on how the student performed and provide further feedback for the

144 Gerald M. Nosich, Learning to Think Things Through: A Guide to Critical Thinking in the Curriculum 7 (2001).

$145 I d$. at 21-32 (summarizing the various impediments to critical thinking).

146 See Amsterdam, supra note 77, at 612 (1984) (describing conceptual process of problem-solving). See also Nosich, supra note 144, at 85-116 (discussing the elements of reasoning).

147 See Linda Morton, Teaching Creative Problem Solving: A Paradigmatic Approach, 34 CAL. W. L. Rev. 375, 382-83 (1998) (discussing phases of creative problem-solving). 
real courtroom experience.

Moving beyond problem-solving skills, clinical educators can help students understand that they can't be prepared for everything and that one of the more important skills for a practitioner in the courtroom is to be flexible. Too often, law school courses impose formalistic, technical approaches to analyzing a case. In the first year, students are exposed to the "right" way to do a case brief and the "right" way to write an exam essay. While clinical supervisors want their students to understand the importance of being thorough in their preparation of a case, clinicians can allow for some time to discuss the need for flexibility once in the courtroom. That flexibility is inevitably dependent on having a heightened awareness to the identity, personality, demeanor and reactions of the judge, jury, opposing counsel, clients and other participants as the case proceeds.

Students also fear (and with good reason) their inability to spot an ethical issue in the midst of court proceedings. Accordingly, an exercise that can help to reduce the students' anxiety is to engage in a simulated review of the applicable Rules of Professional Conduct in the forum, especially those which might come into play in the court proceedings. For example, the clinical professor might pose several ethical dilemmas for student to identify "in the moment" and then evaluate the appropriate resolution of the matters. ${ }^{148}$ The supervisor might also encourage the student attorney to review the Rules and consider which ones might have bearing on the client's case, identify scenarios in which the Rules might come into play, and determine how best to proceed. ${ }^{149}$ Armed with the experience of having applied the Rules within the context of the client's case, the student will likely feel more confident if faced with a situation during the appearance and will be competent in handling it without the intervention of the clinical supervisor.

While these exercises are not meant to be exhaustive, they are intended to move beyond the realm of "stand-up" trial advocacy skills in an attempt to challenge students to be independent critical thinkers and problem solvers. Rather than face the risks associated with an intervention in the midst of court proceedings, clinical educators can attend to this type of pre-court appearance preparation and development in an effort to enhance the educational experience of the student

148 For example, Angela McCaffrey offers several suggested ethical vignettes for students. See Angela McCaffrey, Transforming Minnesota Nice Law Students Into Vigorous, Yet Respectful Advocates: The Value of Simulations in Preparing Clinical Law Students for Ethical and Effective Client Representation, 7 T.M. Cooley J. Prac. \& Clinical L. 91 (2004).

149 See Seielstad, supra note 31, at 202 (suggesting similar exercises for teaching flexibility and adaptability in the face of ethical delimmas). 
during the proceedings, while at the same time imparting greater confidence and competence in the student attorneys they supervise.

\section{B. Post-Court Reflection and Evaluation}

It is not inevitable that students will learn from their experience representing clients. Clinical supervisors have all witnessed examples of students who return from a court appearance and when asked to consider what they learned from the experience, they are unable to do so. Learning for a practitioner must be intentional. ${ }^{150}$ To achieve educational impact from an experience, the student must be challenged to engage in a critical evaluation of the proceedings - of the student's performance, the actions of others in the courtroom, the environment of the proceedings, and the implications for the legal system and the community of all that occurred. It is through exhaustive reflection that the adept practitioner can distill, clarify, and articulate a more refined knowledge of the craft and synthesize theory into practice. ${ }^{151}$

Any courtroom appearance opens the door to an infinite array of topics to discuss in the "post-partum" discussions between the student attorney and the clinical supervisor. ${ }^{152}$ As a supervisor, I continually feel challenged in my ability to reign in and focus these discussions into concrete areas that provide a useful framework for critically examining the experience. Any post-court reflection must involve an assessment of the student attorney's traditional advocacy skills. I find it more challenging, but also more rewarding, for the student and myself to reflect on their problem-solving skills when faced with mistakes or uncertainties during the court appearance and there are several areas upon which I most commonly focus the analysis and ensuing discussions.

The clinical supervisor might best be served by first taking time to sit and reflect on the experience outside the presence of the student ideally while the student is engaging in her own evaluation. This can allow the clinical supervisor to capture his own reflections on the proceedings and begin to organize and make sense of them. The clinical supervisor might jot down ideas, reactions, questions, and areas that the clinical supervisor might explore with the student during the reflective process. It can also be useful to consider what issues might be best addressed in a collective setting with other students, rather than

150 Roland S. Barth, Learning By Heart 65 (2001).

151 Id.

152 I say discussions because it has been my experience that students who come directly out of a court appearance often are unable to engage in a complete critical examination of the experience. While an immediate discussion can be enlightening both for the student and the supervisor, I have found that follow-up discussions after the student and the supervisor have had a little distance to reflect allow for a more nuanced dialogue. 
or in addition to engaging in individual discussions with the student in supervision. In addition to the clinical supervisor's own insights about the experience, the clinical supervisor might take note of what she observed or heard from the client or others present in the courtroom in an effort to enrich the clinical supervisor's own reactions to the student's performance. By engaging in this process before beginning a discussion with the student, the clinical supervisor can be in a better position to choose how to organize and focus the reflective session.

Any post-appearance evaluation with the student should involve a critical examination of all the choice moments that arose during the proceedings. For example, the clinical supervisor might ask the student to identify several such moments and weigh the impact of the action that the student ultimately took. If the student made mistakes or uncertainties arose during the proceedings, the clinical supervisor can help the student determine why that happened and how it might be handled differently in the future. The student might then consider alternatives that she identified and rejected or failed to identify, possible consequences of those alternatives, and why the student rejected, ignored, or did not identify them in the first place. The clinical supervisor can offer examples of choice moments of which the student might not even have been aware. The key to this piece of the debriefing should be to fill in any holes that occurred during problemsolving situations with the goal that the student learn from the experience and avoid such pitfalls by applying that knowledge in the future.

Another helpful area is asking the student to track his/her emotional reactions and to consider how and why those reactions might change with time. Critical thinking is somewhat of a misnomer, in that a central component is the emotive process. ${ }^{153}$ For example, the student might feel elated immediately after receiving a verdict in the client's favor and while the supervisor certainly should not burst the student's bubble, at some point it becomes important to ask the student to consider not only the choices that she made that led to the verdict and whether or not those choices led to the predicted outcome, but also to consider what other choices the student did not identify or whether other choices might have led to a better process to getting to that outcome. ${ }^{154}$ These discussions can sometimes lead the student to think about his orientation towards results to the detriment of process, and how his own motivations and ego can shift the focus too much towards the former. ${ }^{155}$ Students might also feel a range of

153 BROOKFIELD, supra note 88 , at 7.

154 Alternatively, the student might have an array of negative emotions resulting from a verdict against the client.

155 Ann Shalleck has noted that the clinical supervisor can explore with the student the 
emotions after their first glimpse at the operations of a courtroom and the players within it. Such emotions can steer the dialogue into a rich analysis of social justice issues, access to justice, professionalism and professional responsibility, or a critique of procedural or administrative rules.

A post-appearance debriefing session might also focus on the role of the judge and the students' relationship with the judge during the proceedings. ${ }^{156}$ If, as in my students' situation, there were one or more instances in which the students became flustered by a judge, the clinical supervisor might engage the student in a series of questions designed to build on some of the pre-appearance analysis of the role of the judge and other participants in the courtroom. For example, the clinical supervisor can revisit the students' previous consideration of the power of the judge and the need to think critically about the judge's statements and actions as the student should with everything else in the course of the representation. Such a dialogue can re-empower a student attorney to be more pro-active about her position, role and purpose in the courtroom.

The clinical supervisor can enrich these educational experiences for the student attorney by asking the student to think critically about what they witnessed or heard from the judge and other participants during the proceedings and to share those experiences with other students in the clinic. For example, the students might list things that surprised them or that contradicted their assumptions going into the courtroom. They might also relay what they learned of the "unwritten" rules of the courthouse, how they managed those rules, and the consequences for their client's case. ${ }^{157}$ This can also be an ideal time for students to evaluate other lawyers' behavior observed during the proceedings. As noted earlier, a student's exposure to situations in which judges or other practitioners provide incorrect or inappropriate advice can be an eye-opening experience for the student. ${ }^{158}$ Many students enter the clinic with idealized visions of judges as neutral fact-

possibilities and dangers of using results as part of critical reflection; for example, that legal rulings are often not accurate measures of success and that judges, like all of us, are capable of making mistakes. See Ann Shalleck, supra note 39, at 163.

156 In a fictional script of a post-appearance supervisory session, Ann Shalleck offers a glimpse of some of these kinds of questions. See Ann Shalleck, supra note 39, at 135-36.

157 See Seielstad, supra note 31, at 191-97.

158 For example, in another client's case, the same student who was rebuked by the judge in the story relayed at the beginning of this article unknowingly tested my theory that local practitioners and courthouse personnel can provide valuable information about local customs and procedures. When the student sought out and followed the advice of an individual in the courthouse clerk's office about how to amend a complaint and then proceed with service on a defendant whose address was unknown, the advice turned out to be contrary to proper procedure and resulted in further delay. 
finders and accept their pronouncements as the "word of God", not to be questioned. The first court appearance, followed by a debriefing session with the clinical supervisor, inevitably shatters that image. By critically examining the advice through a discussion with the supervisor, students may lose some of the intimidation they might have felt about the judge and digest the reality that judges are human and capable of making mistakes. ${ }^{159}$

A clinic case is likely one of the only times in a law student's professional career when she will have the luxury of engaging in reflection of this depth about even a simple court appearance. By taking the time to instill this habit in their students after each court appearance, clinical supervisors can expect that what may begin as an awkward and at times uncomfortable process for the student will become routine and intuitive for the new practitioner.

\section{Self-Reflection and Evaluation for the Clinical Supervisor}

One of the most useful forms of teaching through modeling is for clinical supervisors to demonstrate their own rigorous self-reflection and evaluation to students. The clinical supervisor, like any good teacher, should always be engaging in a critical examination of what would offer the best educational opportunity and experience for the particular student at that moment, while at the same time balancing the needs of the client and the emotional comfort of the student. As educators, clinical supervisors must challenge themselves to consider how to best prepare their students prior to the appearance. In every supervision situation, whether in court or otherwise, the clinical supervisor is constantly engaging in her own sort of problem-solving, in that she is attempting to gauge the most effective facilitation of the learning process for the student. The supervisor has just as many "teachable moments" as the student attorney. It is incumbent on clinical educators to evaluate their supervisory practices, constantly assessing whether their choices are in line with their educational purposes, whether they adequately prepared and developed the student, and whether they ignored or wrongly decided against certain options. ${ }^{160}$ Through constant evaluation, clinical educators may be surprised that their actions may conflict with their objectives and those they espouse to the students.

159 See Shalleck, supra note 39 , at 164 (noting that students need to separate their own judgments about the effectiveness and quality of their performance from those of the legal system).

160 See Shalleck, supra note 39, at 177 (discussing a series of self-reflective questions that a fictionalized supervisor might ask herself after a supervision session). 
One of the primary areas for self-reflection is the clinician's own motivations and assumptions at play in the supervision of the student attorney. As noted earlier, a clinical supervisor's motives to intervene might be based on more than just a desire to ensure competent representation, such as the clinical supervisor's professional ego, comfort level, or merely a desire to "get back in the game."161 A clinical supervisor's blood might boil and lead her to intervene when, for example, a judge is clearly acting in such a way to clarify his or her position as one of higher authority. Rather than intervene, the clinician might ask herself whether she is being overly protective or paternalistic of the student and/or the client. The clinician might consider the impact of allowing the student the opportunity to experience what the client may have experienced when he or she has confronted such institutions. The clinician might also think about how the student will respond to the opportunity to rebound on one's own and potentially feel the sense of empowerment that results. The clinical supervisor can engage in an honest appraisal of whether he is truly in a better position than the student to assess the needs of the situation and the client, especially if the student attorney has been the primary representative on the case and the client has consented to that. ${ }^{162}$

At every step along the way of supervision, clinical supervisors should be reflecting on the cognitive level at which their students are operating. In the aftermath of a court appearance or, for that matter, any other step in the student's representation of the client, the clinical supervisor should consider whether she accurately calculated the student's ability to problem solve and engage in critical thinking and reflection. ${ }^{163}$ For example, did the student take into account relevant information, including information beyond the realm of the immediate facts of the case? Did the student identify and consider "choice moments" and evaluate a range of consequences for each of those choices? Was the student aware of assumptions that he made during the course of his representation and correct for those assumptions when necessary? Did the student critically examine other participants' conduct and actions and, where appropriate, challenge or ques-

161 Some clinical supervisors have warned that taking complex cases can lead to further tension for the "frustrated practitioner" clinical supervisor to insert herself into the proceedings and take more responsibility for the case. See Ralph S. Tyler \& Robert S. Catz, The Contradictions of Clinical Legal Education, 29 ClEv. ST. L. REv. 693, 701-02 (1980).

162 See Critchlow, supra note 74, at 431-42 (discussing factors such as nature of studentclient relationship, clinical supervisor's familiarity with the case, and client consent when considering intervention).

163 See Aaronson, supra note 80, at 304-05 (noting that clinical supervisors should take into account not only what students might be missing analytically, but also where they are in terms of their own cognitive and emotional development). 
tion it? Did the student resist ownership of the case during the court appearance or depend too heavily on the clinical supervisor for guidance or support? By reflecting on these questions and others, the clinical supervisor engage in a self-appraisal about how she might better have measured and facilitated the student's cognitive development prior to the court appearance in an effort to provide more individualized supervision.

Another aspect of the clinical supervisor's reflective practice requires consideration of how much the clinical supervisor can practically build into the student attorney's preparation for a court appearance. Identifying a list of goals for each student, as well as for the overall program, is a vital component of a clinical supervisor's preparation. Whether it is a semester or year-long clinic, the student's educational experience and the time a clinical supervisor is able to spend on it is limited and requires constant appraisal and adjustment as the realities of the casework dictate. Deadlines and unsynchronized schedules of cases regularly impinge on all that clinical supervisors hope to accomplish. Perhaps the most difficult aspect of the clinical supervisor's job is to decide which educational moment in a case deserves attention and which one must be let go. ${ }^{164}$ The aftermath of a court appearance is one moment in which the clinical supervisor can take stock and evaluate whether she made the right choices in emphasis during the preparation stage by asking herself a series of reflective questions. ${ }^{165}$ Were there moments that the clinical supervisor let go that he should not have? What caused the clinical supervisor stress or anxiety, why did it happen and how might it be avoided in the future? Did anything surprising happen? Were there moments in which the clinical supervisor needlessly emphasized aspects of preparation or did not emphasize enough? The battle in any finite period of time between hard skills and more theoretical training and preparation is a constant balancing act for any clinical supervisor and one that requires constant reflection with every student and every case.

Just as students learn from case rounds discussions, clinical professors can only hope to reflect and grow from their supervision and teaching if they are part of a greater pedagogical dialogue with other clinical supervisors. As part of the self-reflective process, it is vital to include other clinical supervisors in the deliberation. Clinical

164 As Mark Aaronson has noted, "[R]eal life situations are in some ways too textured. There are too many issues on which to follow up. Within the time frame of a semester or even a year, one has to pick and choose selectively the kinds of inquires to be raised with students if an objective is to maintain their attention." Id. at 286.

165 See Gerald F. Hess, Learning to Think Like A Teacher: Reflective Journals for Legal Educators, 38 Gonz. L. Rev. 129, 134-35, 149-50 (2002-03) (posing a series of reflective questions for teachers to consider in evaluating their performance). 
supervisors should routinely engage in "rounds" about supervision, both on a spontaneous, as well as on a more formal level with other colleagues. ${ }^{166}$ Clinical educators must also seek out opportunities for observing others in their supervision and in their teaching, and for others to observe them. For example, clinicians should schedule times to "shadow" a colleague during pre-appearance preparation, as well as in-court supervision and allow for time to talk with the colleague about that process, to ask questions and engage and challenge each other. As Parker Palmer has noted:

Involvement in a community of pedagogical discourse is more than a voluntary option for individuals who seek support and opportunities for growth. It is a professional obligation that educational institutions should expect of those who teach - for the privatization of teaching not only keeps individuals from growing in their craft but fosters institutional incompetence as well. ${ }^{167}$

It is critical that clinical educators also expose their reflection and self-assessment to their students. When the teacher is willing to commit to the difficult task of promoting and modeling his own learning, students will be more likely to take their own learning process more seriously. I have found feedback from students to be very helpful in informing my supervision methods. Students can alert clinicians about whether the supervisor's educational intentions match up to what the students perceive and receive from the experience. Clinical supervisors can also analyze their methods by noting how different students respond. Students may also be helpful in highlighting aspects of the clinician's actions that she might have overlooked in her own self-evaluation. While such feedback might be uncomfortable at times, it is certainly no more uncomfortable than what clinicians ask their students to undertake. ${ }^{168}$ This feedback might be done through journal entries or face-to-face comments during post-appearance supervision meetings. It can be a powerful experience for a student to see her supervisor question choices made along the way that related to

166 Some clinical programs have begun to adopt such discussions, including those at American University's Washington College of Law.

167 Parker J. Palmer, The Courage to Teach: Exploring the Inner Landscape OF A TEACHER's LIFE 144 (1998). Palmer provides examples of exercises in which teachers can candidly discuss their teaching experiences - "those that have perplexed and defeated them, as well as those they have managed with ease." Id. at 145-56.

168 Robert Dinerstein has noted that "when our students write about us or our programs, we may feel exposed in a way that feels uncomfortable but that can give us pause as we think about how those we write about might react to our efforts to derive meaning from our interactions with them .... [M]y students often have very different perceptions from mine regarding our clinical interactions (both substantively and emotionally." See Robert D. Dinerstein, Clinical Education in a Different Voice: A Reply to Robert Rader, 1 CLIN. L. REv. 711, 712 (1995). 
the supervision and strategic planning for the case. ${ }^{169}$

William Quigley noted several years ago that "new clinic teachers will discover that teaching is not so much a task that can be accomplished, but a process that never ends." 170 It is only through on-going reflection and self-assessment that clinical supervisors can hope to grow and refine their supervision of the next generation of lawyers.

\section{Conclusion}

Making full use of all of the educational time available in a liveclient clinic, the clinical professor can help to bridge a fluid connection between the classroom and the practice setting of courtroom for the student attorney. Realistically, clinical supervisors have only a finite period of time with the student attorney and cannot hope to sufficiently prepare every student attorney for every appearance in a courtroom. Nor can they hope to play the same educational role for the students they supervise in court as they might in the classroom. But by placing more emphasis in the curriculum, supervision, and in guided reflection with the students on problem-solving skills necessary to face the novelties and indeterminacies of the courtroom, clinical supervisors can better achieve the clinical educational objective to facilitate the development of students' professional identity, judgment, and values.

By creating a structured path for the development of self-directed learning during the time leading up to the court appearance, the clinical supervisor can ensure that the student attorney is at a place in the learning cycle where more directive tools will be less necessary or even desirable. Peter Hoffman argues that there are stages of the clinical supervisory relationship in which the supervisor moves from being highly directive in the beginning, then to serving as co-counsel, and ultimately to a more non-directive oversight under which the student has primarily responsibility for the case. ${ }^{171}$ While these stages are instructive in theory, the emphasis during a student's development should be less on directing their activities in the representation and more on directing their learning experiences. During the progression of the case leading up to the court appearance, the clinical supervisor should facilitate the development of the student attorney's professional autonomy through the use of theory development, collaborative analysis with peers, problem solving in the context of simulated situa-

169 There is a risk that too much exposure with certain students might encourage them to view it as a weakness and thus overindulge in challenging the clinical supervisor or giving negative feedback on written evaluations.

170 Quigley, supra note 53, at 494.

171 See generally Hoffman, supra note 51. 
tions, and continuous reflection in action. The timing of some court appearances at the beginning of the clinical experience, such as in the case described above, might necessitate more involvement by the supervisor, but clinical supervisors should seek every opportunity to frontload preparation to allow the student to take an active role. ${ }^{172}$

Allowing student lawyers the space in the courtroom to direct their own educational experience with minimal or no intervention by the clinical supervisor during an appearance, while at the same time engaging in a number of exercises prior to and after the appearance, also leads to a richer introduction to one of the primary skills necessary to be a competent, ethical lawyer: problem-solving. The American Bar Association's Report of the Task Force on Law Schools and the Profession, commonly known as the "MacCrate Report", outlines several skills and values deemed by the drafters to be essential for the legal practitioner. ${ }^{173}$ Most important to courtroom practice, the $\mathrm{Re}$ port notes that "a lawyer should be familiar with the skills and concepts involved in problem-solving: identifying and diagnosing a problem, generating alternative solutions and strategies, developing a plan of action, implementing the plan, and keeping the planning process open to new information and ideas." 174 That familiarity is enhanced by actually having the opportunity to practice problem-solving skills while in the context of a live-client court appearance. In addition, the Report notes that identifying and diagnosing the problem includes being familiar with "the legal, institutional, and interpersonal frameworks in which the problem is set" and "systematically and creatively generating potential approaches to the problem"175 When coupled with the exercises described herein, the student attorney will surely meet these expected educational standards when placed into a practice setting in the courtroom.

172 Although the case described above occurred within the first month of the semester, the students rose to the challenge and performed surprisingly well during the trial - and ultimately prevailed. It serves as an example that clinical supervisors should not base their supervisory methods on timing or stages alone.

173 See Report of the Task Force on Law Schools and the Profession: NarROWING THE GAP, published by the American Bar Association Section of Legal Education and Admissions to the Bar (1992) ("The MacCrate Report").

174 Id. at 142.

175 Id. at $142-43$ 
